- Research Branch Technical Report No. 4•

\title{
THE TRI-CREEKS EXPERIMENTAL WATERSHED
}

Changes in Hydrology and Water

Quality Following Forest Harvesting and their Impact on Salmonid Fishes in the Tri-Creeks Basin
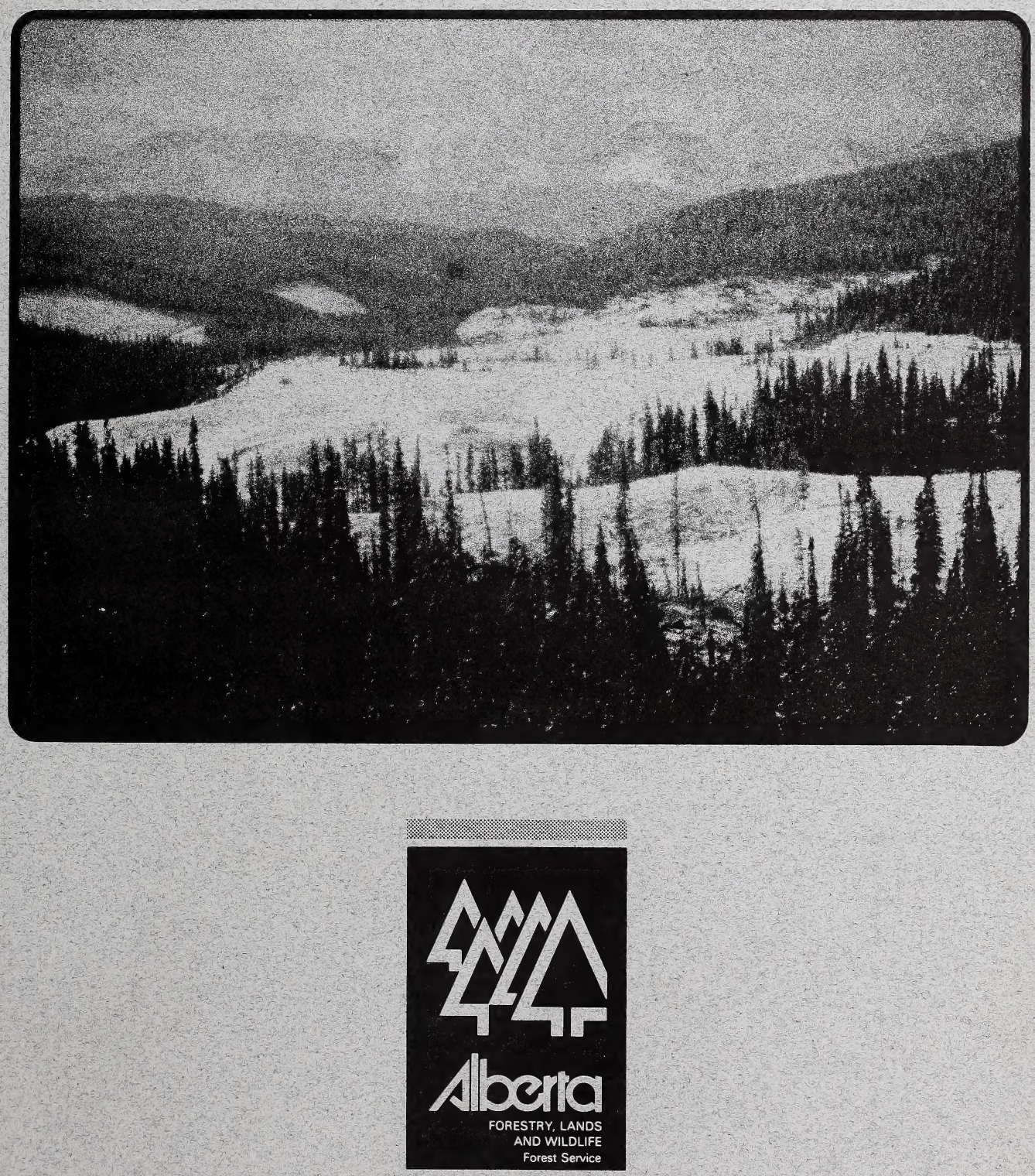

National Library of Canada and Bibliothèque nationale du Canada et
National Archives of Canada 
THE TRI-CREEKS EXPERIMENTAL WATERSHED

CHANGES IN HYDROLOGY AND WATER QUALITY FOLLOWING FOREST HARVESTING AND THEIR IMPACT ON SALMONID

FISHES IN THE TRI-CREEKS BASIN

BY

ALLEN M.-K. NIP

1991

Edmonton 


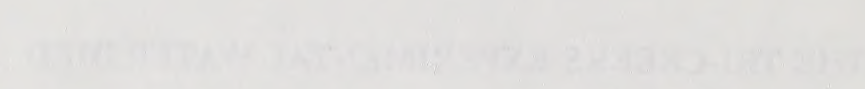

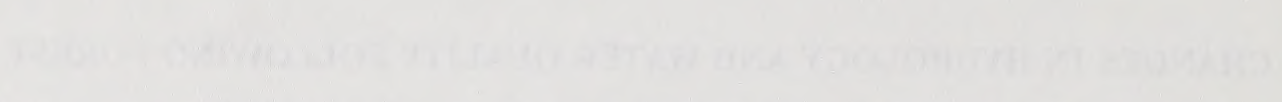
Con

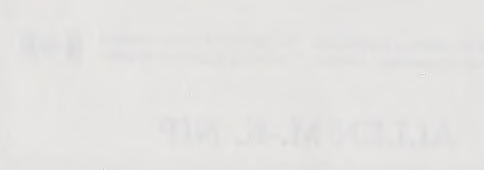

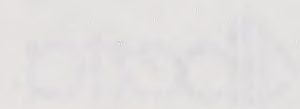


ISBN: 0-86499-617-9

Publ. No. T/199

Copies Available from:

Alberta Forest Service

Forest Research Branch

9920-108 Street

Edmonton, Alberta

T5K 2M4

or

Alberta Forestry, Lands and Wildlife

Information Centre

9920-108 Street

Edmonton, Alberta.

T5K 2M4 
Digitized by the Internet Archive in 2015

https://archive.org/details/changesinhydrolo00nipa 


\section{PREFACE}

The title of this report is "Changes in Hydrology and Water Quality following Forest Harvesting and their Impacts on Salmonoid Fishes in the Tri-Creeks Basin". Such a positively stated title may imply that all the answers regarding forest harvesting impacts on a watershed are to be found inside. It is important to keep in mind that this study was intended to be a test case for a specific watershed basin, thus the extrapolation of the results of this study to other watershed basins should be done with some caution. The author of this report has attempted to pull together the results from over 20 publications related directly to the Tri-Creeks study area. Those publications are all useful and important documents, but only when one attempts to pull it all together to examine interactions do we uncover difficulties in addressing specific questions. These difficulties are not uncommon in these kinds of studies, particularly when they span two decades.

Many of the observations are preliminary because of the problems described above. However, we have still made some valuable observations, often confirming what has been observed in other watershed studies. While the methodologies used in this study do not provide the necessary data to address relationships between the physical, chemical and biological regimes, the overall response of the ecosystem to harvesting and other disturbances, is evaluated by the downstream measurements taken as part of this study. 

The Tri-Creeks Experimental Watershed was established in 1965 to determine the impact of forest harvesting on the population dynamics of major salmonid species and to evaluate the effectiveness of timber harvesting ground rules in protecting fisheries and water resources of two foothills streams in Alberta. Generally, a paired basin approach was used to make these determinations. Harvesting occurred on Wampus and Deerlick Creek basins in accordance with Alberta Forest Service harvesting ground rules established for North West Pulp and Power Co. (presently Weldwood Canada Ltd., Hinton Division) Forest Management Agreement area (consolidated version, Schultz and Co. Ltd., 1973). A small portion of Wampus and Deerlick Creek basins was logged under prescribed General Operating Conditions. Deerlick Creek basin was harvested in a similar manner except that treed buffer strips were removed for experimental purposes. Eunice Creek basin remained undisturbed and was used as a control basin.

Most of the results to follow were based on a lumped approach where the harvest and the postharvest phase were combined together in a single "postharvest" phase. The true postharvest phase lasted a maximum of three years. Monitoring of the watershed for the intended five years would have provided more time to detect changes following harvesting and a larger data set for statistical analysis. Nevertheless, the observed changes and trends discussed below were generally similar to those reported elsewhere in Alberta, Canada and the United States.

No significant differences in water yield between the unlogged and logged basins were observed following timber harvesting. However, the trend was towards an increase in water yield following logging. The groundwater table followed the topography. Stream baseflow was largely derived from shallow groundwater. Preliminary results indicated total snow accumulation of the cutblock was greater than the adjacent residual forest. However, the distribution of snow in the cutblock was more variable than in the adjacent forest. 

Whan 
A significant increase in total phosphate as well as decreases in $\mathrm{pH}$, nitrate-nitrite and ammonia were observed following logging. The magnitude of these changes were small, and did not cause any deterioration in water quality following harvesting. Suspended sediment yield increased significantly during and following road construction in Deerlick basin and following harvesting in both basins. Road construction was the major contributor of sediment entering Deerlick Creek. Point sources of sediment were generally not controlled effectively.

Point sources, present in buffered and unbuffered cutblocks, were the primary source of sediment input into the watercourse. Mean maximum stream temperature during July and August increased 3.0 and $5.4^{\circ} \mathrm{C}$ in Wampus and Deerlick Creek, respectively, following logging. Removal of streamside buffer strips magnified the increase in water temperature.

The above environmental changes following timber harvesting did not adversely affect the aquatic biota on a short term basis. The salmonid population showed considerable fluctuations, sometimes declining despite a lack of obvious impacts. The impact of logging did not negatively affect spawning habitat. Warmer stream temperatures correlated highly with shorter time periods in reaching peak spawning, hatching, and emergence. An increase in fish growth in some age classes was detected following logging. Benthic macroinvertebrate populations were highly variable but did not appear to be negatively affected by sediment entering the stream channel from a point source.

Due to the absence of provincial guidelines outlining acceptable changes to water quality, quantity and timing, it was difficult to evaluate the effectiveness of harvesting ground rules in protecting the watershed and aquatic environment. However, changes in hydrology and water quality in the Tri-Creeks watershed following harvesting did not have a detectable negative effect on the fish and macroinveterbrate populations. Fewer environmental impacts on the aquatic environment may be expected if the current, much improved and more stringent ground rules and operating conditions are carefully followed and enforced. 



\section{TABLE OF CONTENTS}

Page

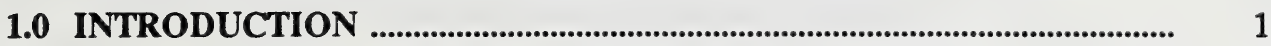

1.1 Study Objectives .................................................................................. 1

1.2 Basin Description .................................................................................... 2

1.2.1 Location of Study Area ........................................................... 2

1.2.2 Vegetation ..................................................................................... 2

1.2.3 Aquatic Biota .............................................................................. 3

1.2.4 Geology and Soils .................................................................. 7

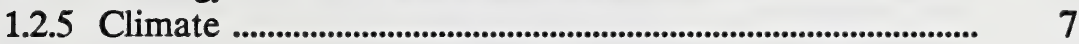

1.3 Treatment ............................................................................................. 8

2.1 Streamflow .......................................................................................... 11

2.1.1 Objective ................................................................................ 11

2.1.2 Methods ................................................................................... 12

2.1.3 Results and Discussion ........................................................... 12

2.2. Snow

2.2.1 Objective ............................................................................. 16

2.2.2 Methods .......................................................................................... 17

2.2.3 Results and Discussion ........................................................ 18

2.3 Groundwater .................................................................................... 20

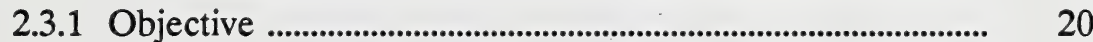

2.3.2 Methods .......................................................................................... 20

2.3.3 Results and Discussion ......................................................... . 20

3.0 WATER QUALITY .................................................................................... 21

3.1 Surface Water Chemistry ...................................................................... 23

3.1.1 Objective ................................................................................ 24

3.1.2 Methods ......................................................................................... 24

3.1.3 Results and Discussion ............................................................ 25

3.2 Suspended Sediment .................................................................................. 28

3.2.1 Objective ............................................................................... 28

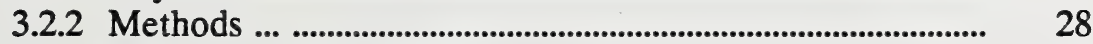

3.2.3 Results and Discussion ............................................................ 29

3.3 Water Temperature ....................................................................................... 36

3.3.1 Objective ................................................................................. 37

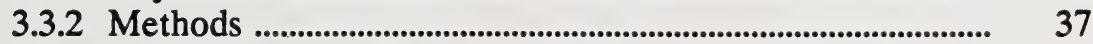

3.33 Results and Discussion ....................................................... 37 

4.1 Effects of Stream Sedimentation on

Macroinvertebrate Populations

4.1.1 Objective

4.1.2 Methods

4.1.3 Results and Discussion

4.2 Population Dynamics of Major Salmonid Species

4.2.1 Objective

4.2.2 Methods

4.2.3 Results and Discussion

4.3 Impacts of Forest Harvesting on Salmonids

5.0 FOREST MANAGEMENT IMPLICATIONS

7.0 CONCLUSION 


\section{,}




\section{ILLUSTRATIONS \\ LIST OF FIGURES}

Figure

Page

1. Location of Tri-Creeks Experimental Watershed

2. Location of instrumentation gauges in the Tri-Creeks basin ...................... 5

3. Cutblock locations in the Tri-Creeks Basin ..................................................... 6

4a. Streamflow between Wampus and Eunice Creeks ......................................... 14

4b. Streamflow between Deerlick and Eunice Creeks ........................................ 14

5a. Water yield in May in Wampus Creek ............................................................. 15

5b. Water yield in August in Deerlick Creek ....................................................... 16

6. Cutblock, inner and outer forest zones ....................................................... 17

7. Snow accumulation in forest and cutblock ................................................... 19

8. Variability in snow accumulation ..................................................................... 19

9. Variability in sediment yield ............................................................................ 30

10. Sediment yield between Wampus and Eunice Creeks ............................ $\quad 30$

11. Sediment yield between Deerlick and Eunice Creeks .............................. 31

12a. Haul road after construction ........................................................................... 32

12b. Haul road after stabilization ..................................................................... 32

13. Suspended sediment and turbidity from a point source .............................. 35

14. Removal of streamside buffer strip along Deerlick Creek ....................... 36

15a. Comparison of July maximum water temperature between Wampus and Eunice Creeks _.................................................... 39

15b. Comparison of July maximum water temperature between Deerlick and Eunice Creeks ..................................................... 39

16. Rainbow trout density in Lower Eunice, Deerlick and Eunice Creeks 46

17. Rainbow trout density in Upper Eunice, Deerlick and Eunice Creeks 47 



\section{ACKNOWLEDGEMENTS}

Special thanks to Dr. K.O. Higginbotham and G.B. Maier for recognizing the value of the study and providing the support and opportunity to conclude the Tri-Creeks project. The author would like to thank S. Ferdinand, T. Lakusta, and B. Northey, of the Alberta Forest Service, G. Sterling of the Alberta Fish and Wildlife and Dr. R. Rothwell of the University of Alberta for their time and assistance in providing valuable comments on this report. Sincere thanks to Dr. P. Tsui and T. Sneddon for their support and guidance throughout this project and M. Laird for her editorial review. 



\subsection{INTRODUCTION}

The eastern slopes of the Rocky Mountains are the primary source of flowing water for the prairie provinces, as well as providing important sport fish habitat. In the 1960s, the prospect of large scale forest harvesting by logging companies operating under quotas and newly developed Forest Management Agreements created concern about the impacts of logging on fisheries production and the chemical and physical regimes of Alberta foothill streams. The lack of information in Alberta concerning logging impacts, coupled with public concern about the possible resulting degradation of foothill streams and implementation of untested ground rules provided the impetus for the Tri-Creeks Experimental Watershed Research study. The commencement of the International Hydrologic Decade by the United Nations Educational, Scientific and Cultural Organization further promoted the study of water resources.

\subsection{Study Objectives}

The original study objectives were as follows:

1. to determine the effects of clearcutting on the survival, growth and reproduction of fish and aquatic invertebrate populations;

2. to determine the effects of streamside timber removal on water temperature, streamflow and suspended sediment;

3. to determine the effects of clearcutting on the hydrological regime;

4. to determine the effects of road construction and clearcutting on suspended sediment concentrations and stream channel siltation; and

5. to determine the effects of clearcutting on the hydrochemical regime.

These objectives were used to evaluate the effectiveness of forest harvesting ground rules in protecting fisheries and watershed resources. 



\section{LIST OF TABLES}

Table

1. Physiographic characteristics of the subwatersheds ...................................... 3

2. Optimal water quality requirements of salmonid populations ................. 22

3. Mean pre- and post-harvest water quality ........................................................... 25

4. Sediment yield ratio .................................................................................................. 33

5. Sediment loading at point sources in Wampus Creek ................................. 34

6. Mean monthly maximum stream temperature ................................................. 38

7. Percent fry escapement ......................................................................................... 50 

The following study objectives were added to the study during the post-harvest phase to help provide insight into the hydrological and the hydrogeological regime.

1. to determine differences in snow accumulation, ablation and distribution between a large cutblock and adjacent residual forest;

2. to determine the contribution of ground water flow systems to the chemistry, temperature and flow of surface waters; and

\subsection{Basin Description}

A paired basin approach, in which physiographically similar watershed basins were compared before and after forest harvesting, was used in this study. Eunice Creek basin remained undisturbed for the duration of the study, and served as the control. The basins of Wampus and Deerlick creeks were harvested in the same manner with the exception of Deerlick basin, where streamside buffer strips within cutblocks were removed for experimental purposes.

\subsubsection{Location of Study Area}

The Tri-Creeks Experimental Watershed study area is located $40 \mathrm{~km}$ southeast of Hinton, Alberta at $53^{\circ} 09^{\prime} \mathrm{N}$ and $117^{\circ} 15^{\prime} \mathrm{W}$. A map of the study area is shown in Figure 1. Figures 2 and 3 illustrate the topography, instrumentation, harvesting and silvicultural treatments imposed. Physiographic characteristics of the basin are detailed in Table 1.

\subsubsection{Vegetation}

The Tri-Creeks watershed basin is classified as subalpine/upper boreal cordilleran (Archibald 1987). The subalpine zone, occupying the higher elevations (1350 to $1650 \mathrm{~m}$ ) of the study area, is forested by Engelmann spruce (Picea engelmannii), subalpine fir (Abies lasiocarpa) and lodgepole pine (Pinus contorta var. latifolia). The upper boreal cordilleran 

zone, occupying the lower elevations (1270 to $1350 \mathrm{~m}$ ), is characterized by lodgepole pine and white spruce (Picea glauca) on well drained sites and black spruce (Picea mariana) on wetter sites.

Table 1. Physiographic Characteristics of the Subwatersheds

Characteristics

Total area $\left(\mathrm{km}^{2}\right)$

Maximum elevation (m)

Main channel length $(\mathrm{km})$

Stream gradient $(\mathrm{m} / \mathrm{km})$

Drainage Density $\left(\mathrm{km} / \mathrm{km}^{2}\right)$

Stream order $(1: 15000)$

Area cut (ha)

$\begin{array}{ccc}\begin{array}{c}\text { Eunice } \\ \text { (control) }\end{array} & \begin{array}{c}\text { Wampus } \\ \text { (ground rules) }\end{array} & \begin{array}{c}\text { Deerlick } \\ \text { (ground rules but } \\ \text { removal of buffers) }\end{array}\end{array}$

16.1

1680

28.2

1707

14.8

9.0

15.8

34.9

18.9

1680

10.1

2.9

3

0
2.1

3

1058.4
25.6

2.8

(Currie 1969, Jablonski 1978a, and Jarvis 1984)

\subsubsection{Aquatic Biota}

Rainbow trout (Oncorhynchus mykiss) is the predominant fish species within the TriCreeks basin (Dietz 1971, Sterling 1978). Mountain whitefish (Prosopium williamsoni) utilize the streams as foraging areas in late spring and summer and as spawning areas in the fall. Bull trout (Salvelinus confluentus) predominate in the lower reaches of Eunice Creek (Sterling 1980).

Mayflies (Ephemeroptera), stoneflies (Plecoptera), caddisflies (Tricoptera) and midgeflies (Diptera) are the dominant orders of aquatic invertebrates found in Tri-Creeks (Zelt, 1970). 



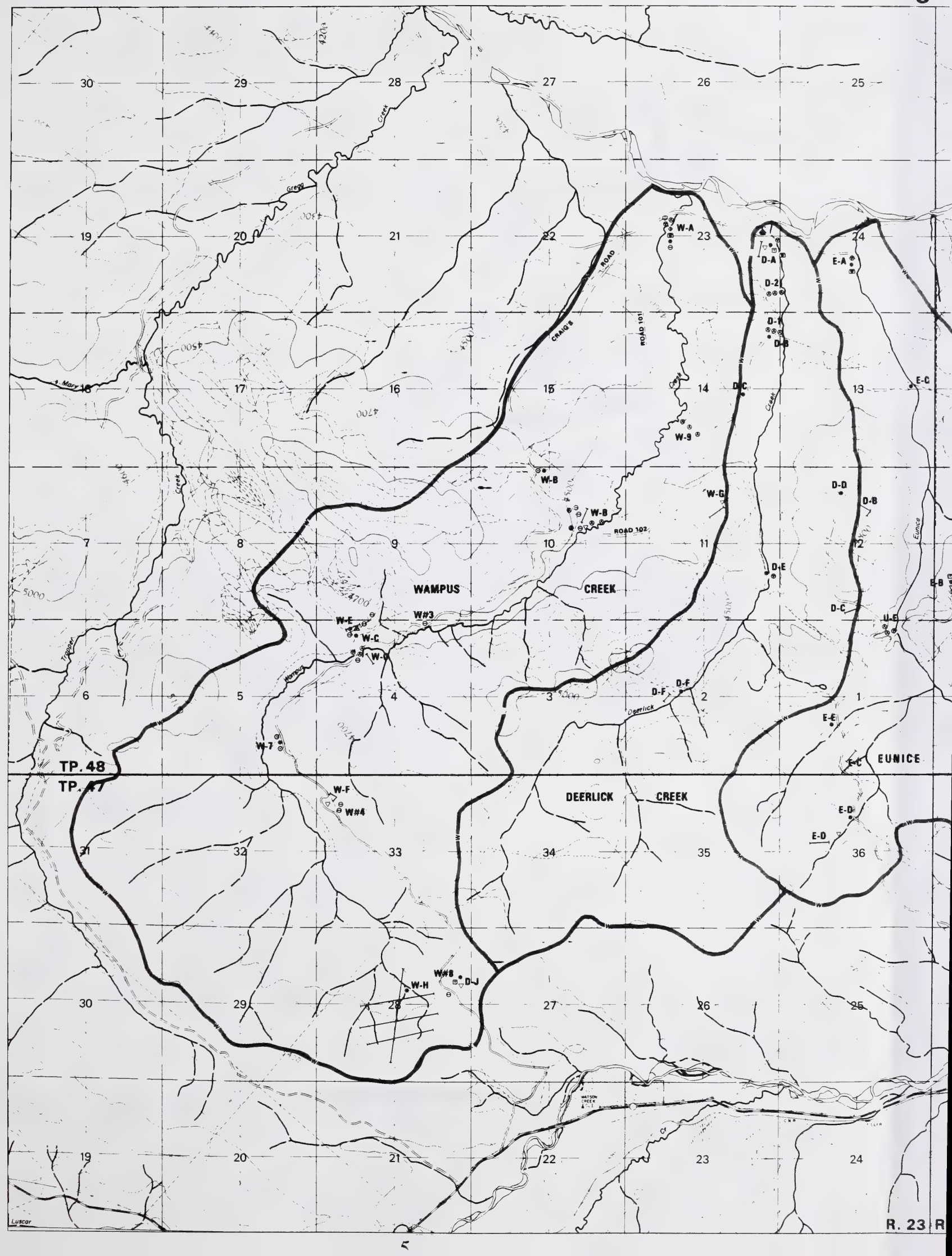


Figure 2: Location of instrumentation gauges in the Tri-Creek Basin.

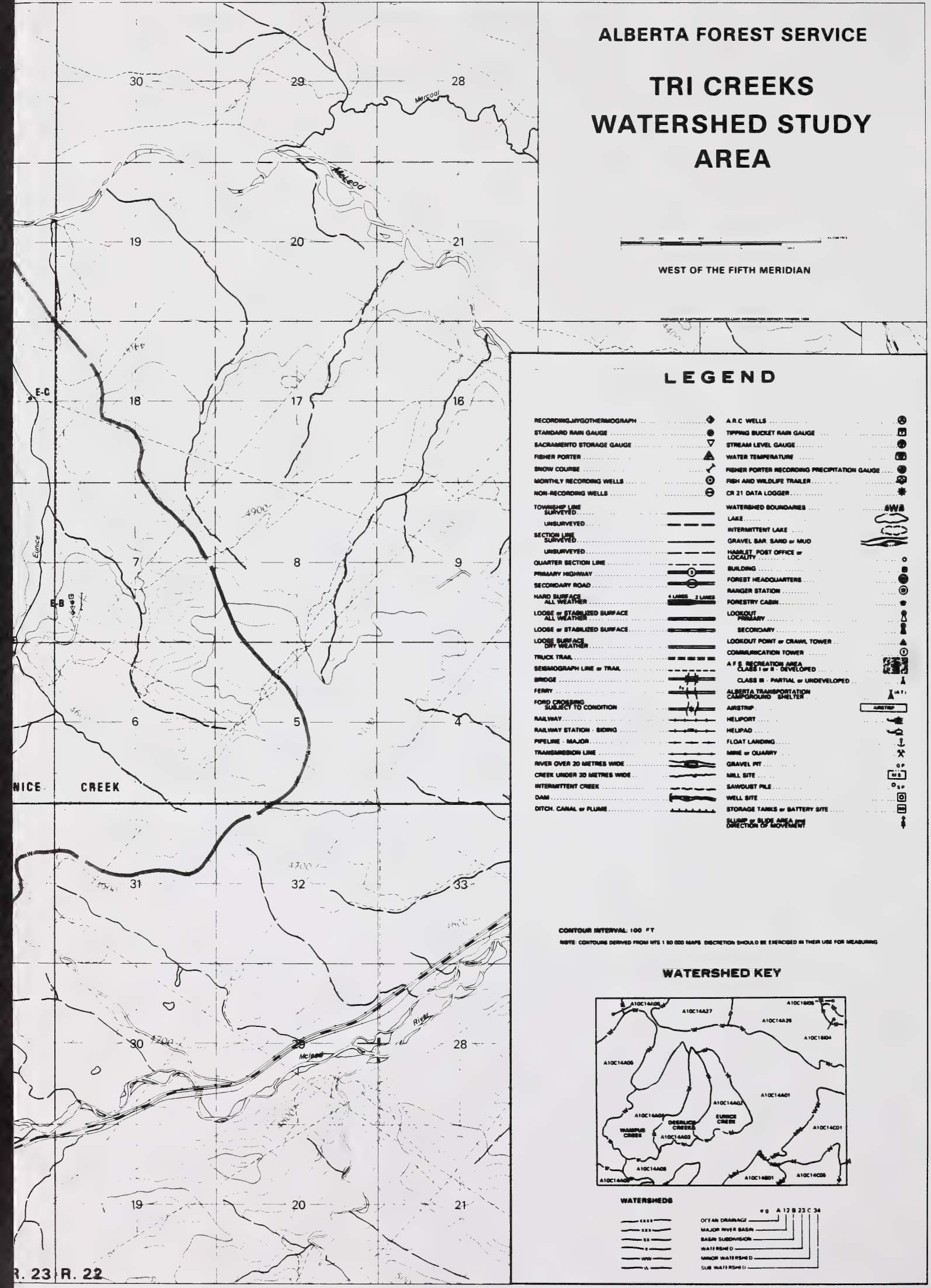




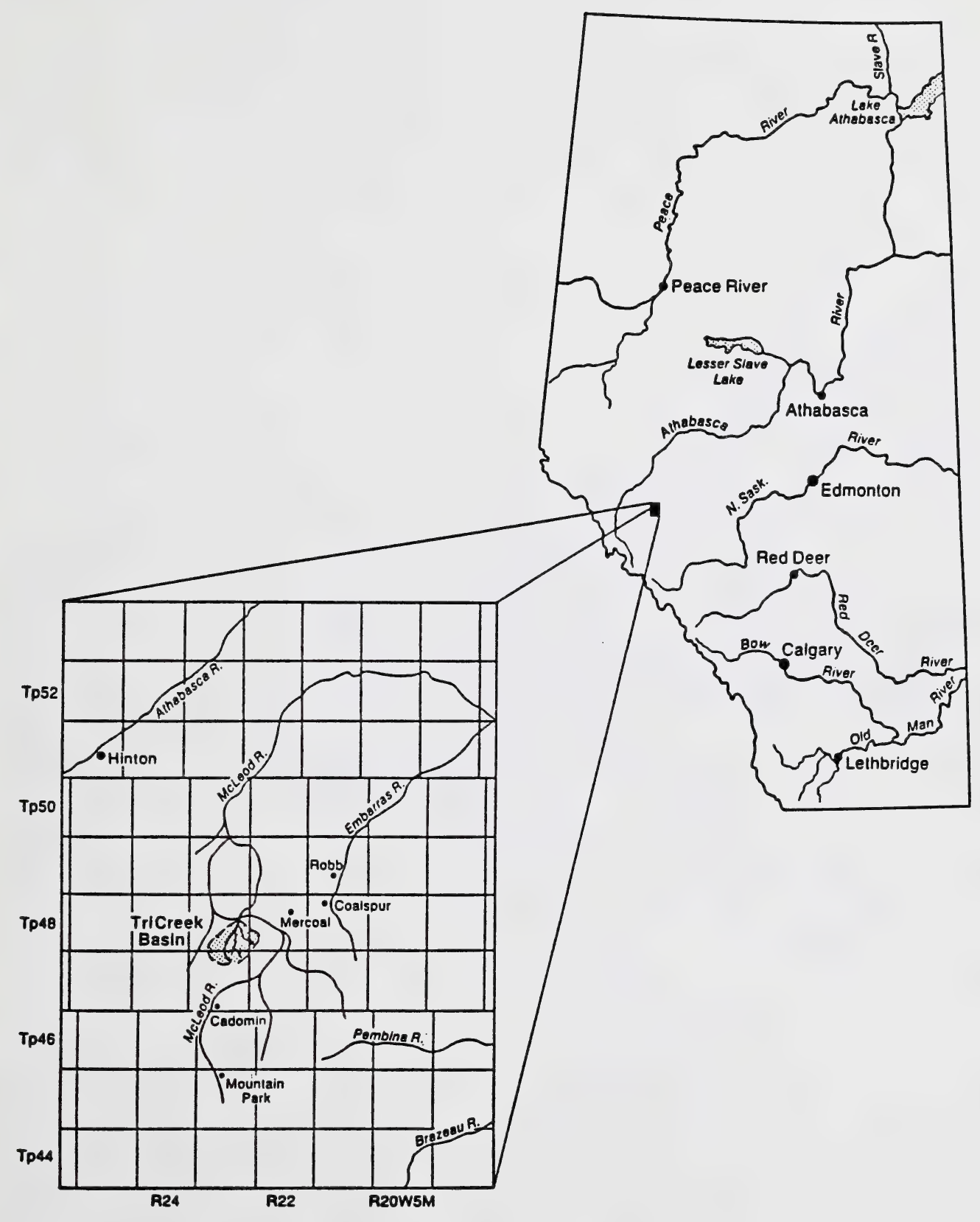

Figure 1. Location of the Tri-Creeks Experimental Watershed 



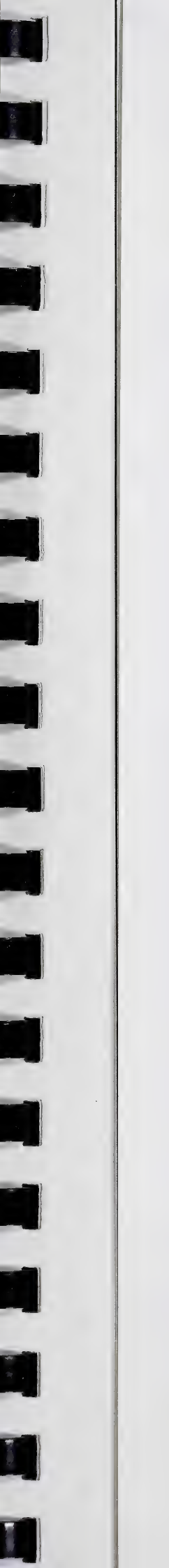





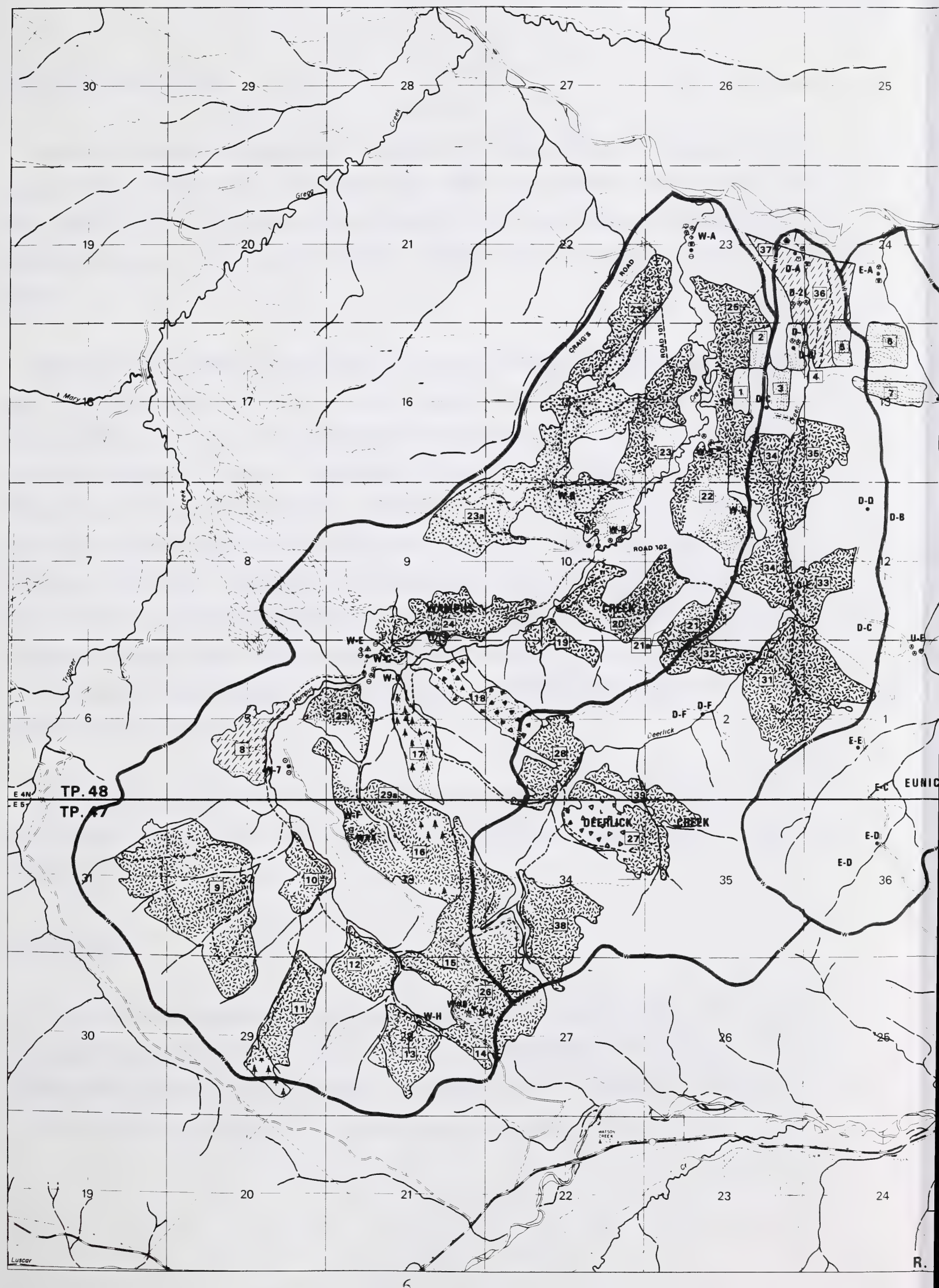


Figure 3: Cutblock locations in the Tri-Creek Basin.

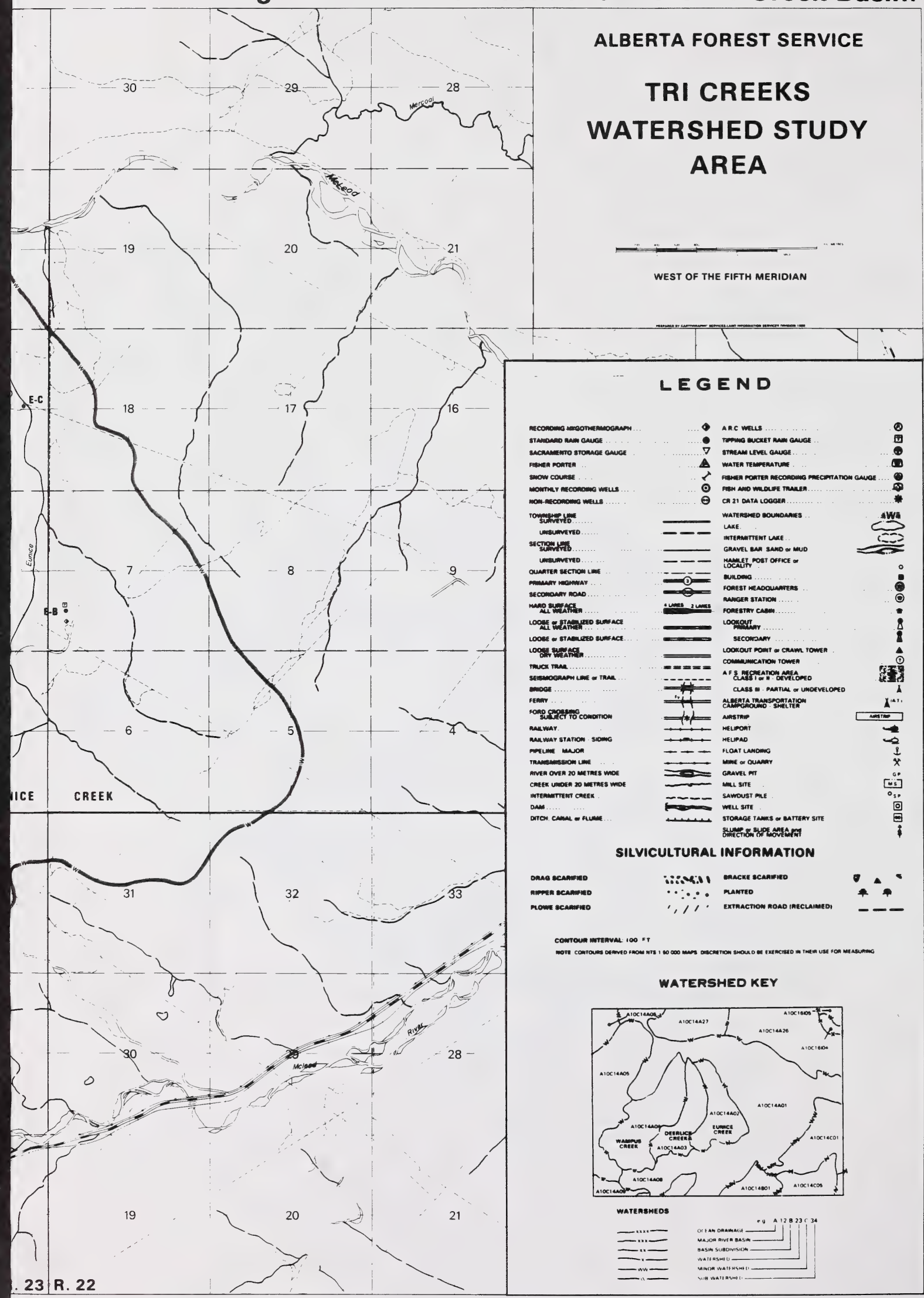




\subsubsection{Geology and Soils}

The Tri-Creeks basin, located in the foothills belt, is characterized by southwest dipping thrust sheets in which the strata have been folded and uplifted (Currie 1969). The fragmented rocks belong to the Brazeau formation of the late Cretaceous period and local exposures belong to the Wapiabi, Cardium and Blackstone Formations of the Alberta Group.

Dumanski et al. (1972) identified two till deposits: Marlboro till and an unnamed local till. Medium-textured cordilleran till covers much of the upper slopes of the watershed, while medium textured glaciolacustrine deposits dominate the valley bottoms with organic material in depressional areas. Three major soil associations were identified in the TriCreeks area (Dumanksi et al 1972). The Marlboro association was the most common, covering approximately 50 per cent of the watershed area. It consists of Luvisolic soils developed on medium- to fine-textured cordilleran till. The Robb association, occupying 18 per cent of the study area, consists of Brunisolic and Luvisolic soils developed on till and colluvium materials. The Tri-Creeks association, consisting of Luvisolic soils developed on fine to medium textured glaciolacustrine sediment, occupies the lower portion of the study area on gentle to steep slopes.

Soil erodibility was calculated using the Universal Soil Loss Equation (Wischmeier and Smith, 1965). Hudson et al. (1985) rated the soils as highly to extremely highly erodible in 70 per cent of the study area.

\subsubsection{Climate}

The Tri-Creeks climate is characterized by cool, wet summers and long, cold winters interrupted by occasional warm Chinook conditions. Precipitation increases, and relative humidity decreases with rising elevations. Mean daily maximum temperatures range from $-4.8^{\circ} \mathrm{C}$ in January to $19.9^{\circ} \mathrm{C}$ in July. Mean annual temperature was $1^{\circ} \mathrm{C}$, but ranged from 

$0.3^{\circ} \mathrm{C}$ at lower elevations to $2.1^{\circ} \mathrm{C}$ at upper elevations (Olson and Hastings 1989). Lower mean temperatures at lower elevations are caused by nocturnal cold air drainage to valley bottoms.

Mean annual precipitation is $855 \mathrm{~mm}$, ranging from an average of $770 \mathrm{~mm}$ at low elevations to $918 \mathrm{~mm}$ at higher elevations (Olson and Hastings 1989). Approximately $36 \mathrm{per}$ cent of annual precipitation falls as snow and 64 percent as rain. An average of $550 \mathrm{~mm}$ of rain falls on the Tri-Creeks basin during the growing season. The maximum rainfall in a single day was $130 \mathrm{~mm}$ in August 1969; the highest rainfall intensity was $18 \mathrm{~mm} / \mathrm{h}$. Maximum snowpack usually occurs in March.

Mean annual wind speed at Edson, approximately $70 \mathrm{~km}$ northeast of Tri-Creeks, is $8.0 \mathrm{~km} / \mathrm{h}$ with maximum wind gusts over $100 \mathrm{~km} / \mathrm{h}$ recorded at lookout towers near Tri-Creeks. High wind gusts have caused blowdown in buffer strips as well as along edges of cutblocks. For further details on the climate of the Tri-Creeks basin, refer to Olson and Hastings (1989) and Jablonski (1978b).

\subsection{Treatment}

Fifty per cent of the merchantable timber (predominantly lodgepole pine), amounting to 39 and 40 per cent of the total watershed area on Wampus and Deerlick creeks basins respectively was clearcut in alternate cutblocks. Alberta Forest Service harvesting ground rules (consolidated version, Schultz and Co. Ltd., 1973), established for Northwest Pulp and Power Co. Forest Management Agreement area in 1973 were applied to the harvesting operations of Wampus and Deerlick Creek basins with the exception of the southern portion of Wampus and Deerlick Creek basins where General Operating Conditions for the Commercial Timber Permit were applied. Treed buffer strips were left along the cutblock streamside of Wampus Creek but were removed for experimental purposes along Deerlick Creek. Construction of the main haul road (102) began in the fall/winter of 1974/75 and 

was completed in 1978. Harvesting was conducted during the winter in order to minimize soil disturbance. Cutblock sizes ranged from 13 to 200 ha in Wampus Creek basin and 20 to 114 ha in Deerlick Creek basin with mean cutblock size of 58 and 50 ha respectively. The larger cutblocks ( 4 out of 34) exceed the maximum cutblock size of 100 ha permitted under present timber harvesting operating ground rules (Alberta Forestry, Lands and Wildlife, 1986). Logging was conducted by St. Regis (Alberta) (currently Weldwood Canada Ltd. and formerly Northwest Pulp and Power Co.) using machinery and/or hand felling with chain saws. Timber was hauled to landing sites by skidders and then transported to the mill in Hinton, Alberta. Silvicultural treatments of the cutblocks for reforestation included drag, ripper or Bracke scarification. Scarification was completed within one year of harvest.

The hydrological, hydrogeological, hydrochemical and climatic regimes were monitored throughout the entire study. The project was divided into study phases as follows:

1. Preharvest calibration:

2. Main access road construction and preharvest data evaluation:

3. Forest harvesting:

Wampus Creek

Deerlick Creek

4. Postharvest monitoring:

Wampus Creek

Deerlick Creek
1965 to 1975

1975 to 1978

1979 to 1983

1980 to 1984

\title{
8
}

1984 to 1986

1985 to 1986

\begin{abstract}
All three basins were monitored for 10 years prior to harvesting to establish the preharvest regression relationships between Wampus and Eunice creeks and Deerlick and Eunice creeks. To permit separation of effects of the road construction from timber harvesting, the main haul road was constructed four years prior to harvesting. The forest harvesting phase, intended to be as short as possible so the effects of harvesting would not be confounded by other variables, was increased by two years because of insufficient amount of merchantable
\end{abstract}



timber removed for the treatment. The postharvest phase was shortened from 5 to 3 years because of administrative reasons and budgetary constraints. Post-harvest monitoring was conducted more intensively than prior to the harvest phase. As a consequence of a limited post-harvest data set, harvest and postharvest data in most cases were combined and analyzed as a "postharvest" data set. The rationale for this was to secure a larger data set. The data sets were combined in accordance to the study phases outlined in the previous page. Pre and postharvest data were compared to determine if forest harvesting caused any measurable change in streamflow, precipitation, surface water quality, groundwater and aquatic ecology. 



\subsection{HYDROLOGIC IMPACTS OF FOREST HARVESTING}

The water balance, can be described by an equation where the hydrologic inputs (precipitation) of a basin are equal to the outputs (sur mation of stream discharge, evapotranspiration and change in groundwater storage). It is the most common method of detecting hydrologic changes in a watershed basin. Timber harvesting can alter the components of a water balance. Bosch and Hewlett (1982) reviewed 94 experimental catchment basins and concluded reduction of forest cover can increase water yield and the increases are highly variable. Other harvesting impacts include alteration of snow accumulation, distribution and ablation in forest openings (Swanson 1980; Tabler and Schmidt 1973) and soil and water movement rates and pathways (Anderson et al. 1976; Hewlett and Hibbert 1967). These impacts can alter the hydrology of a watershed and subsequently the fisheries of a harvested basin.

\subsection{Streamflow}

Studies conducted in the United States show timber harvesting can result in an increase in water yield (Hibbert 1967). Swanson and Hillman (1977) detected seasonal water yield increases of 27 per cent for the period of April 25 to September 15 and average increases of 1.5 to 2 times in storm flow from nine logged (35 to 85 percent clearcut) watersheds near Hinton, Alberta.

\subsubsection{Objective}

The objective of this study was to determine if timber harvesting had a measurable impact on the timing and quantity of streamflow. 



\subsubsection{Methods}

Streamflow and stage levels at the outlets of Eunice, Deerlick and Wampus creeks were monitored during the open water season between spring runoff and fall freezeup of each year for the duration of the study. Streamflow sampling frequency varied, with a greater number of measurements taken during the postharvest phase, spring runoff and storm events. Daily and hourly flows were estimated from stage-discharge rating curves.

The first measurement of the rising limb of the snowmelt hydrograph was compared with the previous year's last measurement of the fall hydrograph to determine whether the rising limb of the snowmelt hydrograph was measured or excluded from the snowmelt hydrograph.

Two approaches, a lumped regression analysis and a double mass curve, were used to compare the water yield, of Wampus and Deerlick creeks to those of Eunice Creek (Figures $4 \mathrm{a}$ and $4 \mathrm{~b}$ ). Water yield was adjusted for a given precipitation. Open water yields during the harvest phase were treated as part of the postharvest phase. Regression analysis was used to determine differences in: 1 . peak flow during the snowmelt hydrograph; 2 . open water yield; and 3. monthly water yield between the treated and control watersheds. Unit hydrographs were developed for the analysis of summer storm hydrographs. The total change in annual water yield could not be calculated due to an incomplete record of spring runoff and an absence of winter runoff data. The gauging stations froze in late fall and did not thaw until late spring. Heating of the gauging stations during the ice period would have permitted year-round operation and help define the annual water yield.

\subsubsection{Results and Discussion}

With the exception of 1967 to 1969 inclusive, most of the rising limb of the snowmelt hydrograph was measured. Seasonal water yield prior to harvesting for Wampus, Deerlick and Eunice creeks were 243, 236 and $216 \mathrm{~mm}$, respectively. Following harvesting, mean 

water yield were 261, 287 and 213 for Wampus, Deerlick and Eunice creeks, respectively. The higher flows suggest an increase of $18 \mathrm{~mm}(7 \%)$ and $51 \mathrm{~mm}(22 \%)$ for Wampus and Deerlick creeks, respectively, which compare favorably with an increase of $42 \mathrm{~mm}$ (27\%) near Hinton, Alberta with a similar intensity of cut (Swanson and Hillman, 1977). Examination of figures $4 a$ and $4 b$ suggest that the changes observed were attributed to normal variability over time. Analysis of data indicate no significant differences $(p=0.05)$ in water yield between the before and after treatments. The lack of significance was attributed to the short duration of the post harvest phase to clearly define the post harvest regression, part of the rising limb of the snowmelt hydrograph was not acccounted for, and an extended treatment period.

Examination of the double mass curves also suggest an increase in water yield following harvesting. There was a clear change in slope in the Wampus-Eunice plot in 1979, the year after $16 \%$ of the watershed area was logged. In the Deerlick-Eunice plot, 2 shifts in slope were detected. The first shift in 1975 may be caused by the relocation of the gauging station and/or the removal of timber for the construction of the haul road. The second shift occurred in 1984, after the logging was completed.

The observed changes in water yield can be attributed to a reduction of evapotranspiration losses following harvesting. The reduction amounted to 28 and $48 \mathrm{~mm}$ in Wampus and Deerlick Creek, respectively. The amount of water yield increases was similar to the reduction in evapotranspiration losses following logging in Deerlick Creek. However, there was a larger discrepancy in Wampus Creek. There were 3 possible factors accounting for this discrepancy. An underestimation of precipitation in Wampus basin (19 $\mathrm{mm}$ less than Deerlick basin) would result in a larger reduction in evapotranspiration losses. The second factor was the possible leakage of Wampus basin into the adjacent basin (Trapper Creek) (Don Currie, pers. comm.). Without the leakage, it would result in a larger water yield than presently observed. The third factor was the recovery of some of the cutblocks to a vegetative condition in Wampus Creek (Frank Davis, pers.comm.). This would decrease the reduction in evapotranspirative losses observed. 


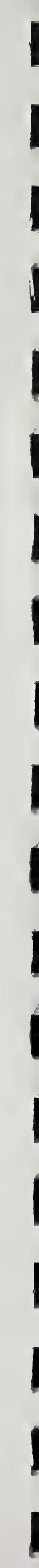




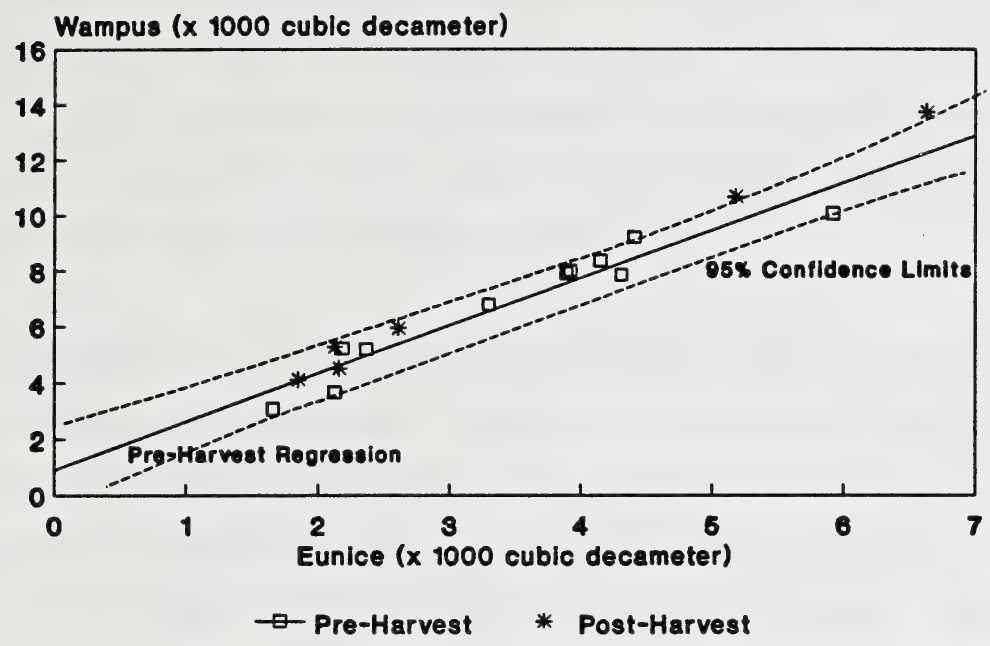

Andres ot al. (1987)

Note: Postharvest phase is shown for comparison only.

Figure 4a. Streamflow Between Wampus and Eunice Creeks

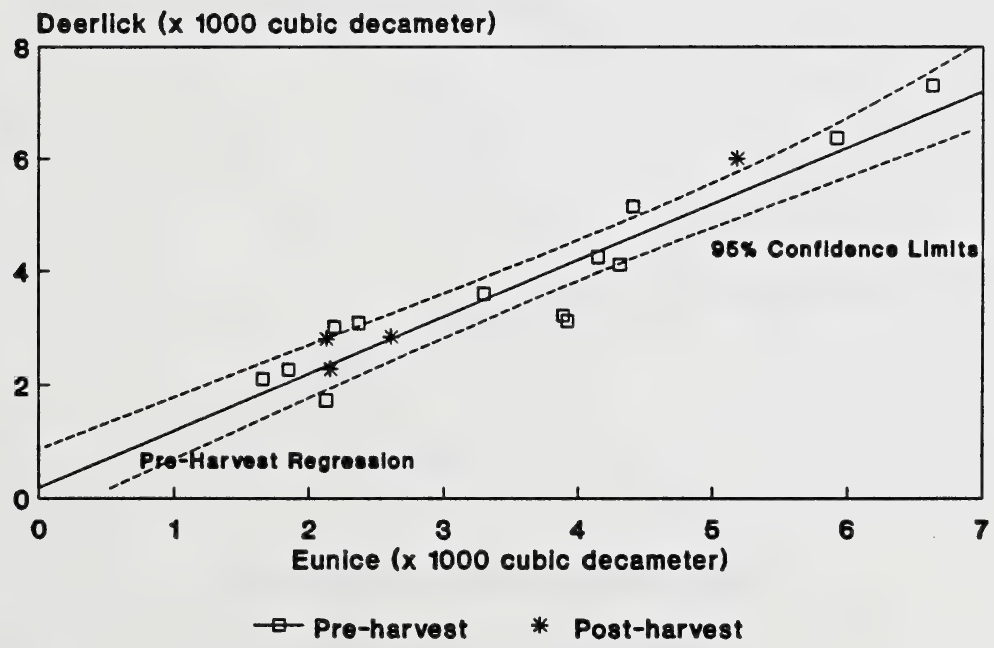

Andres ot al. (1987)

Note: Postharvest phase is shown for comparison only.

Figure 4b. Streamflow Between Deerlick and Eunice Creeks 

Monthly water yield during the open water season tend to increased following harvesting. The largest volume increase occurred in May and June during the snowmelt period, a trend demonstrated in other studies (Swanson and Hillman, 1977; Leaf, 1975). Percentage increases in flow were most noticeable in May (Figure 5a) in Wampus Creek and in August (Figure 5b) in Deerlick Creek.

No significant differences in peak spring runoff following logging were detected. This was attributed to the incomplete record of the rising limb of the snowmelt hydrograph. Summer peak flood analysis suggest that an increase of $47 \%$ in peak flow occurred as a result of clearcutting $40 \%$ of the watershed area. Changes in peak flows were correlated (93\%) with the amount of area cut in Deerlick basin, however, this was not the case in Wampus basin. No significant differences between preharvest and postharvest summer storm hydrographs were detected. This was attributed to the high variability in the spatial and temporal distribution of storm events (Andres et al.,1987). For further information on the hydrologic regime, refer to Andres et al. (1987).

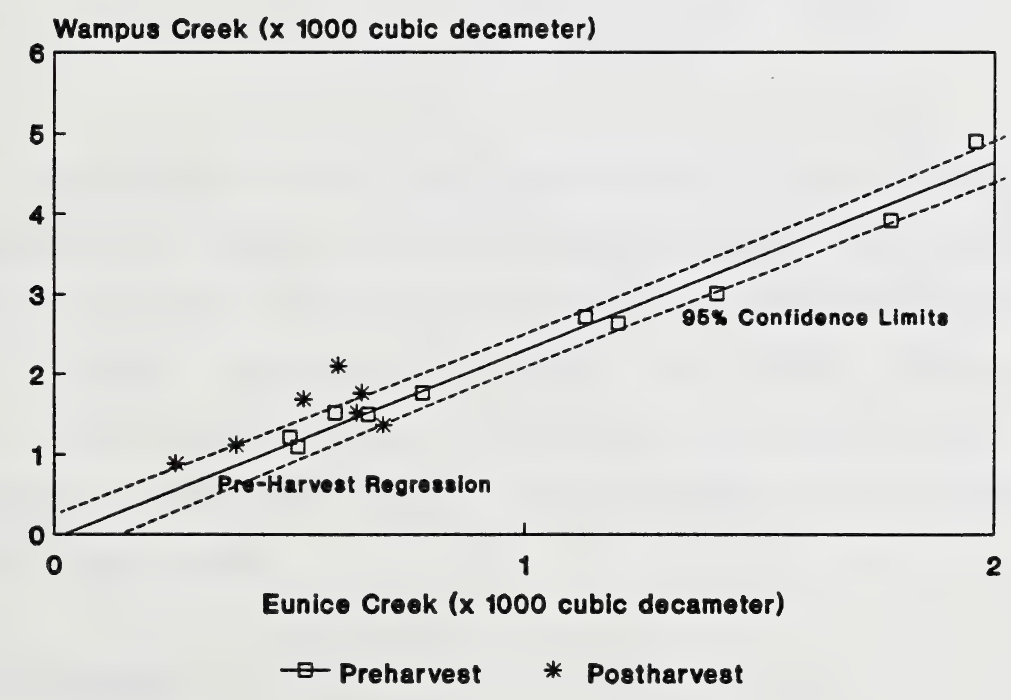

Andree ot al. (1087)

Note: Postharvest phase is shown for comparison only.

Figure 5a. Water Yield in May in Wampus Creek 


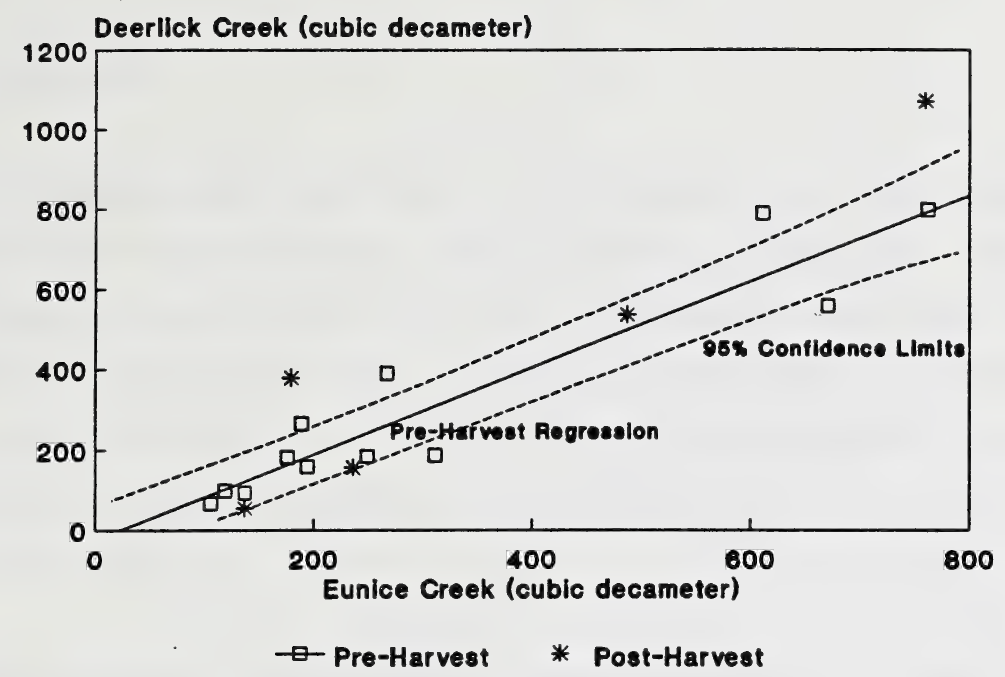

Andres et al (1987)

Note: Postharvest phase is shown for comparison only.

Figure 5b. Water Yield in August in Deerlick Creek

\subsection{Snow}

The creation of an opening in a forest can alter the aerodynamic flow of blowing snow. Large cutblocks (greater than 15 tree heights in width in the windward direction of the prevailing winds) can reduce the total amount of snow retained at ground surface (Troendle and Leaf 1980). The amount of snow cover in the cutblock could be critical to the growth and survival of tree seedlings. Snow cover can provide protection to seedlings from dessication and freezing temperatures, and is a major source of soil moisture for vegetation growth in the spring.

\subsubsection{Objective}

The objective was to determine the difference in snow accumulation, ablation and distribution between a large cutblock and adjacent residual forest. 



\subsubsection{Methods}

The depth, density and water equivalent of snow cover were measured monthly in 1984/85 and 1985/86 in cutblock 13 in the Wampus Creek basin. The cutblock, situated in rolling topography with a northern aspect, is irregularly shaped and occupies a total area of 37.8 ha. Sampling sites were established at 20 -m intervals across the cutblock and 300 $m$ into the residual forest in a north-south and east-west direction. Another cutblock was with similar topographic conditions was established in Gladstone valley in southwestern Alberta as a replicate.

Snow water equivalent was area-weighted. For analysis, the residual forest was divided into two zones: the inner forest and the outer forest (Figure 6).

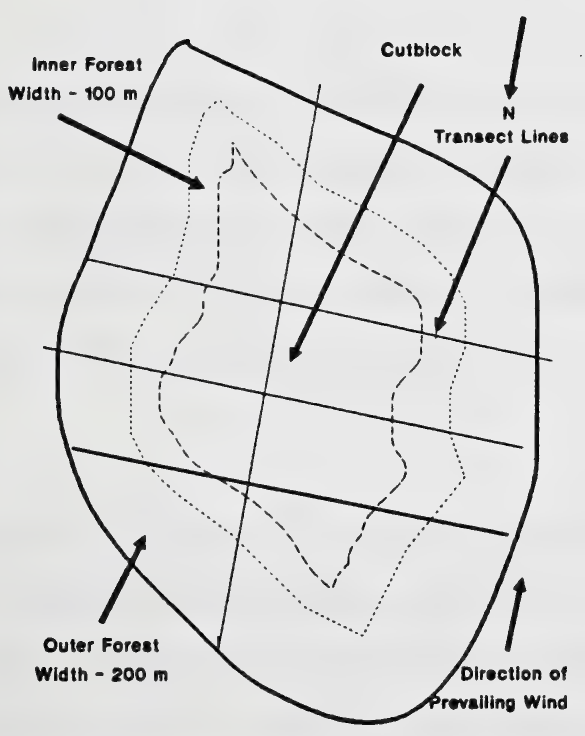

Figure 6. Cutblock, Inner and Outer Forest Zones 

The snow cover in the inner forest zone was thought to be influenced by the cutblock. However, the snow cover in the outer forest zone was not considered to be influenced by the cutblock (Nip and Swanson 1985). Student t-test was used to determine differences between the cutblock and residual forest.

\subsubsection{Results and Discussion}

The following are preliminary results of cutblock 13. Similar results were observed in Gladstone valley. No significant differences $(p=0.05)$ were detected between the snow water equivalent (SWE) of the cutblock and inner forest and the cutblock and the outer forest. The general trend was SWE in the cutblock was greater than the average of the inner/outer forest. This was a result of reduced interception losses in the cutblock. Figure 7 illustrates SWE in the winter of 1983-84. Similar results were observed in the winters of 1984-85 and 1985-86. The lower SWE in the cutblock in mid-April was due to the faster snowmelt because of direct sunlight compared to the shaded conditions of the forested environment.

The general trend is SWE in the cutblock and forest were similar but noticeable greater than those in the outer forest. Snow water equivalent generally declined from cutblock to the inner forest to the outer forest. Higher variability in SWE was observed in the cutblock (Figure 8) when compared to the inner forest. The least variability in SWE was observed in the outer forest. This suggest snow redistribution occurred in the cutblock and inner forest.

Some areas received less than $5.0 \mathrm{~cm}$ of water equivalent for the entire winter (Figure

8). These areas occurred mainly in the center of the cutblock. In areas where little snow has been received or retained during the winter season, snowmelt recharge to the soil mantle in the spring may be minimal. The forest management implications of such conditions are discussed in section 5.0 of this report. 



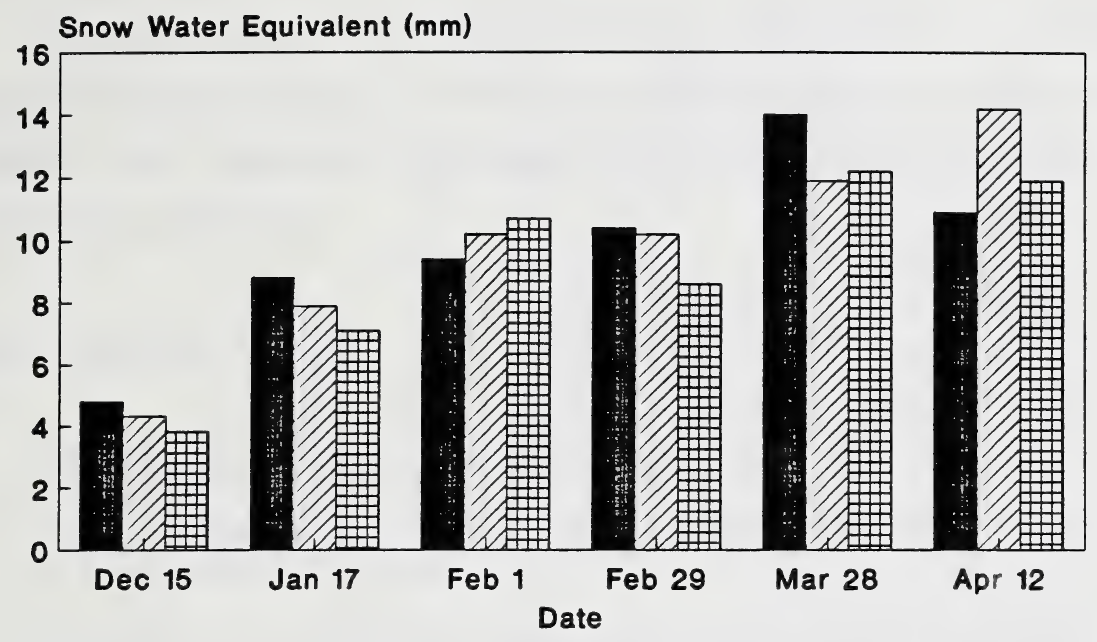

Cutblock $\square Z$ Inner Forest Outer Forest

Figure 7. Snow Accumulation in Forest and Cutblock

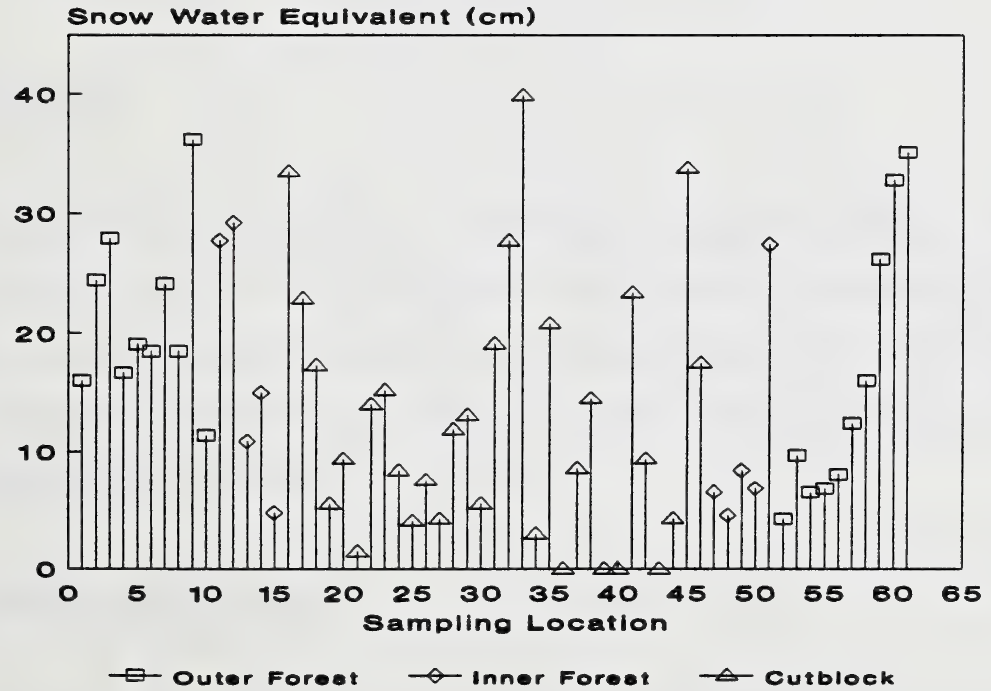

Figure 8. Variability in Snow Accumulation 



\subsection{Groundwater}

Forest harvesting can alter infiltration and percolation processes by compacting the soil, and removing the duff layer. Postharvest silvicultural treatment can cause similar changes. Surface water chemistry, temperature and stream discharge can also be influenced by groundwater discharge.

\section{$\underline{\text { 2.3.1 Objective }}$}

The objectives of this project were to determine:

1. assess the relative contribution of shallow and intermediate groundwater flow systems to the baseflow of streams;

2. assess the contribution of groundwater flow systems to the chemistry of surface water and;

3. assess the relationship between the surface water temperature and groundwater temperature.

\subsubsection{Methods}

The depth to water tables for a forested area and clearing were monitored in 1985 and 1986. Piezometers were laid in a transect in forested and unforested areas. Surface and subsurface water chemistry samples and water temperature data were collected from both sites. Groundwater parameters monitored included total dissolved solids, $\mathrm{pH}$, alkalinity, conductivity and major ions.

\subsubsection{Results and Discussion}

The water table was found to follow the topography of the Tri-Creeks basin. Determinations of oxygen-18 and deuterium levels in shallow groundwater wells were found 

to be virtually indistinguishable from surface water. Tritium concentrations in shallow groundwater overlapped with those of surface waters. Hydrochemically, shallow groundwater was similar to surface water; both were of calcium-magnesium-bicarbonate type. Intermediate depth groundwater was of sodium-bicarbonate type. This indicated base flow to a large extent was largely derived from shallow groundwater. This also suggest that any land use activities affecting shallow groundwater systems will also affect surface waters.

Stream temperatures were approximately $3.5 \mathrm{C}^{\circ}$ higher compared to shallow groundwater. This can be attributed to heat influx into the streams (Andres et al, 1987). No significant differences were detected between groundwater temperature of loggged and unlogged basins. For further information, refer to Andres et al. (1987). 



\subsection{WATER QUALITY}

Foothills streams in Alberta are generally regarded as cold, oligotrophic and pristine. Salmonids such as rainbow trout, mountain whitefish and bull trout are known to inhabit pristine environments. The optimal biological requirements of salmonids are summarized in Table 2. Within certain life history stages, water quality requirements may be more stringent than those listed in Table 2.

Table 2. Optimal Water Quality Requirements of Salmonid Populations

Parameter

Suspended Solids

Iron

Nitrate

Nitrite

Total Phosphate

Ammonium Ion

$\mathrm{pH}$

Dissolved Oxygen

Temperature
Criterion

less than $10 \mathrm{ppm}$

$0.30 \mathrm{ppm}$

$30 \mathrm{ppm}$

$0.6 \mathrm{ppm}$

0.005 to $0.015 \mathrm{ppm}$

$0.98 \mathrm{ppm}$

6.5-8.5

$6.5 \mathrm{ppm}$

$13-15^{\circ} \mathrm{C}$
Reference

Longmore and Stenton, 1981

Longmore and Stenton, 1981

Longmore and Stenton, 1981

Longmore and Stenton, 1981

International Joint Commission, 1981

International Joint Commission, 1981

Longmore and Stenton, 1981

Wallace and Strong-Duffin, 1985

U.S. Water Pollution Control

Administration, 1968

The trophic state or productivity of a biological system is determined by the presence and concentration of phosphate, nitrate and silica, the temperature regime and dissolved oxygen (International Joint Commision 1980). The Commission found that phosphate is the most significant limitation to primary production in freshwater. These trophic states are defined with respect to orthophosphate concentrations in the water column during the spring season:

State

Oligotrophy

Mesotrophy

Eutrophy
$\mathrm{PO}_{1}$ Concentration

0 to $0.010 \mathrm{ppm}$

0.011 to $0.020 \mathrm{ppm}$

Greater than $0.020 \mathrm{ppm}$

Forest land use disturbances such as forest harvesting can alter the water quality of these streams. Studies conducted at Hubbard Brook Experimental Watershed in New Hampshire, U.S.A have shown an export of nutrients (nitrate-nitrite, $\mathrm{Na}, \mathrm{Ca}$ and $\mathrm{Mg}$ ) into 


$$
\text { . }
$$


the stream channel following harvesting (Likens et al. 1970). Similar changes but of much lower magnitude were reported by Hewlett (1979) in catchment basins in Piedmont, Georgia and at Nashwaak Experimental Watershed project in New Brunswick (Powell, 1982).

Road construction activities associated with logging are the major contributor to increased levels of suspended sediment (Burns 1972, Ritchie 1972, Anderson 1976, Rothwell 1979). Erosion caused by skidding and scarification can also contribute to an increase in suspended sediment loading in stream channels. Such changes can degrade fish habitat and production.

Changes in stream temperature may also occur following removal of streamside vegetation (Brown and Krygier 1970). Large increases in stream temperature may be considered as thermal pollution while small increases may be beneficial to stream productivity if natural temperatures are low. The following discussion focuses on surface water chemistry, suspended sediment and stream temperature.

\subsection{Surface Water Chemistry}

Increases in nutrient export from clearcut areas were reported from several catchment basins within the lease area of Weldwood Canada Ltd. near Hinton, Alberta (Singh and Kalra 1977). The increases were attributed to the following:

1) an increase in forest slash and debris;

2) increase in litter decay and subsequent release of nutrients; and

3) greater exposure of mineral soil to erosional and weathering processes.

Nutrient export to stream channels and the subsequent reduction of site nutrients may have significant implications for forest site and stream productivity. Site nutrient losses may affect forest regeneration. High levels of nutrient influx into the stream channel may cause enrichment to occur. Small increases in nutrient export to the stream channel could prove beneficial to oligotrophic streams by enhancing stream productivity. 



\subsubsection{Objective}

The objective was to determine whether a change in the surface water chemistry regime occurred in the treated watersheds following harvesting.

\subsubsection{Methods}

Modified grab samples, which were depth integrated samples similar to those taken with a standard U.S.D.A. DH-48 sampler, were collected throughout the project at each outlet of the three streams. Frequency of sampling varied, with more samples taken during the spring runoff period and storm events than during base flow conditions. More samples were also collected during the postharvest phase than in other study phases. Chemical analyses were performed, in accordance with standard methods outlined by the American Water and Wastewater Association and Water Pollution Control Federation (1966), by Environment Canada and the Alberta Environmental Centre. Determinations included specific conductance, sodium, calcium, potassium, silica, nitrate + nitrite, ammonium, total Kjeldahl nitrogen, total or particulate nitrogen, total phosphate and orthophosphate. Field determinations included $\mathrm{pH}$, turbidity and specific conductance. Data collected between 1975 and 1983 were not included in the database due to a change in laboratory analytical techniques.

Lane (1975) observed a stable relationship between discharge and the concentration of inorganic ions. He also reported that specific conductance can be related to both discharge and to constituent ion concentrations. Having established the preharvest condition, a significant change in the inorganic chemistry regime could be detected by:

1. A parameter change in the relationship between stream discharge and specific conductance;

2. A change in the ratios amongst major ions; and

3. A change in the relationship between specific conductance and the major ions; 

A significant change in the organic chemistry regime may be detected by:

1. A parameter change in the relationship between stream discharge and parameter concentration;

2. A change in the dependency of silica concentration to the nitrogen to phosporus ratio $(\mathrm{N} / \mathrm{P})$ by season, which is an index of eutrophication; and

3. A change in carbon versus the $\mathrm{N} / \mathrm{P}$ ratio by season (Sneddon, 1990).

For hydrochemical parameters dependent on discharge, a stable relationship between stream discharge and each constituent was established. Regresssion analysis was used to compare preharvest (1967-74) to postharvest (1984-86) data for a particular basin to determine whether changes have occurred following timber harvesting. Data analysis for Eunice Creek was identical to the harvested basins to determine whether changes occurred for the same time period. For parameters that are independent of discharge, the baseline average concentrtion was statistically compared with the same parameter during the postharvest period. A paired basin analysis was not possible due to an insufficient number of years of postharvest data for proper analysis.

\subsubsection{Results and Discussion}

Table 3 summarizes the mean pre and postharvest chemical determinations found during the ice-free period. There is a strong seasonality component in the data. Specific conductance, not significantly different between the pre and postharvest period, decreased in all three streams following harvesting. A general dilution curve, where specific conductance decreased with increased flow, was similar to ones reported by Lane (1975).

Significant decreases $(p<0.001)$ in nitrate and nitrite and ammonia were observed in all three creeks following logging. Similar decreases were observed in Piedmont, Georgia (from 0.16 to $0.11 \mathrm{mg} / \mathrm{l}$ in the control basin and 0.05 to $0.02 \mathrm{mg} / 1$ in the treated basin (Hewlett, 1979). Scrivener (1982) reported decreases for the first 2 years following logging, followed by an increase in concentration in Carnation Creek, British Columbia. There were 


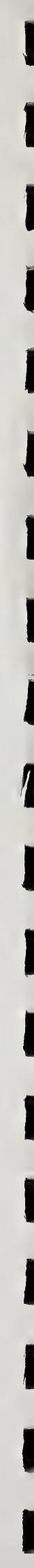


no significant differences detected in total alkalinity, turbidity, sulfate, sodium, calcium, potassium, magnesium, and silica loadings between pre and postharvest periods.

A significant increase $(p=0.01)$ in total Kjeldahl nitrogen was observed in Eunice Creek from 1984 to 1986. In contrast, no significant difference was detected in Wampus Creek and no changes were detected in Deerlick Creek following harvesting. Particulate nitrogen was not measured in the preharvest period but was found to peak at the time of needle fall, spring freshet and fall rains in the postharvest phase. These results are similar to those reported by Gosz et al. (1972).

Table 3. Mean Pre- and Post-harvest Water Quality

\begin{tabular}{|c|c|c|c|c|c|c|}
\hline \multirow[t]{2}{*}{$\begin{array}{l}\text { Surface Water } \\
\text { Chemistry }^{\mathrm{a}}\end{array}$} & \multicolumn{2}{|c|}{$\begin{array}{c}\text { Eunice } \\
\text { (control) }\end{array}$} & \multicolumn{2}{|c|}{$\begin{array}{c}\text { Wampus } \\
\text { (groundrules) }\end{array}$} & \multicolumn{2}{|c|}{$\begin{array}{l}\text { Deerlick } \\
\text { (ground rules but } \\
\text { val of buffer strips) }\end{array}$} \\
\hline & Pre & Post & Pre & Post & Pre & Post \\
\hline Conductivity & 186 & 172 & 158 & 141 & 163 & 157 \\
\hline Silica & 8.56 & 9.06 & 8.50 & 8.76 & 8.12 & 9.06 \\
\hline Nitrate + Nitrite & 0.08 & 0.04 & 0.04 & 0.03 & 0.05 & 0.03 \\
\hline Ammonium & 0.10 & 0.01 & 0.06 & 0.02 & 0.06 & 0.02 \\
\hline Total Kjeldahl Nitrogen & 0.23 & 0.26 & 0.32 & 0.30 & 0.35 & 0.35 \\
\hline Total Phosphate & 0.02 & 0.02 & 0.02 & 0.04 & 0.02 & 0.03 \\
\hline Total Alkalinity & 91 & 97 & 73 & 80 & 74 & 93 \\
\hline $\mathrm{pH}$ & 8.10 & 7.88 & 7.94 & 7.72 & 8.00 & 7.90 \\
\hline Turbidity & 0.39 & 0.37 & 0.63 & 0.86 & 0.81 & 0.63 \\
\hline
\end{tabular}

a Conductivity in microsiemens/cm $\mathrm{pH}$ in $\mathrm{pH}$ units

Turbidity in Log Transformed Nephelometric Turbidity Units All other values expressed in parts per million.

(Sneddon 1990)

A significant increase $(\mathrm{p}<0.01)$ in total phosphate loading was detected in Deerlick and Wampus creeks following harvesting while no changes were detected in Eunice Creek for 
the same time period. Singh and Kalra (1977) compared untreated and treated watershed basins and found mean phosphate concentrations of 0.15 and $0.16 \mathrm{mg} / 1$ for the untreated and treated basins, respectively. The change in phosphate concentrations following logging in Wampus and Deerlick creek basins may have contributed to an increase in algal productivity in these basins. Hartman (1981) observed similar responses in the Carnation Creek watershed in British Columbia. Nutrient (nitrate and phosphate) loading increased, resulting in increased primary production following logging.

Preharvest particulate (total) and dissolved organic carbon were not measured, thus no inferences about the effects of forest harvesting can be made. Similarities in carbon concentration between the treated and untreated basins during the postharvest period suggested that carbon enrichment associated with logging debris did not occur.

A significant decrease $(\mathrm{p}<0.01)$ in $\mathrm{pH}$ occurred in all three watersheds. Wampus and Eunice creeks showed the largest decrease ( $0.2 \mathrm{pH}$ units), followed by Deerlick Creek ( 0.1 $\mathrm{pH}$ units). A large but insignificant increase in turbidity levels was detected in Wampus Creek following harvesting. In contrast, a small decrease was observed in Deerlick Creek. Eunice Creek showed no changes in turbidity for the same period.

Statistically significant changes in $\mathrm{pH}$, inorganic nitrogen and total phosphate were observed in the control and treated basins in the before and after comparisons. However, it is important to recognize that the changes were small in magnitude and did not cause a deterioration in water quality following harvesting. Increased total phosphate loading appeared to stimulate algal production, thereby increasing eutrophy into a nutrient poor stream such as those found in Tri-Creeks. Generally, the changes in surface water chemistry detected in both the control and logged basins was attributed to normal variability over time rather than to forest harvesting. A more detailed monitoring program, better analytical procedures coupled with a stream productivity study, and a longer postharvest monitoring period would be necessary to identify possible changes in water chemistry and its impact on stream productivity. For further information, refer to Sneddon (1990). 


\subsection{Suspended Sediment}

Many studies (Beschta 1978; Rothwell 1979a) have investigated the impact of forest harvesting on sediment regime. Most conclude that any increase in suspended sediment concentration can be attributed to excessive soil disturbance such as road construction, stream crossings, skidding activity and scarification. Additional sediment loadings may be result from increased streamflow causing channel scouring. The effects of increased sediment loading on aquatic biota are widely documented (Griffiths and Walton 1978; McCart and deGraff 1974). Such effects include: a reduction in photosynthetic activity; abrasion of gills inhibiting respiratory and excretory functions of fish and aquatic insects; suffocation of fish eggs; and decreased visual feeding activity.

\subsubsection{Objectives}

The objectives were to:

1. determine whether there is a difference between seasonal basin sediment yield before and after harvesting;

2. determine whether there is a difference in sediment yield between buffered and unbuffered streams; and

3. determine whether there is a difference in sediment loading between a site above and below a point source.

\subsubsection{Methods}

Modified paired grab samples were collected at several non-point and point sources in the watershed. A non-point source is defined as a specific area where the source(s) of sediment entering the stream channel are unknown or are diffuse. A point source is a specific area where the source of sediment entering the channel is known.

Non-point source (samples taken at the mouth of the creeks) sampling was the primary 


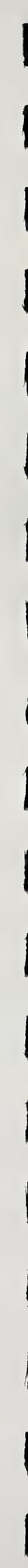


method of sampling. Sampling frequency varied, with more samples collected during the spring runoff and storm events and during the postharvest phase. Sampling was conducted at three to six hour intervals during storms. Suspended sediment concentrations were determined using standard gravimetric filtration methods while turbidity was measured with a turbidimeter. Stream discharge was measured immediately after taking a grab sample. Daily sediment loads were calculated by multiplying daily estimated stream discharge and suspended sediment concentration during the ice free period. Daily mean suspended sediment concentrations and flow were estimated from a varied number of measurements, from several taken during storm events to once every few days during base flow. Monthly sediment loads were the summation of daily sediment loads. Since more samples were collected during the postharvest phase, more confidence can be placed on these data than earlier information. For analysis, sediment yields of the harvest and postharvest phase were combined together into the "postharvest" phase. The road construction phase was treated separately in Deerlick Creek basin. Regression analysis (control vs treated basins) was used to compare sediment yield before and after treatment. Sediment yield ratios were calculated by dividing the mean sediment yield of one basin by those of another basin for each study phase. Storm sediment hydrographs were analyzed for hysterisis.

In point source analysis, actual sediment concentrations and discharge measurements during storm events were used for comparing sites above and below a point source. Sampling occurred at several locations along Wampus and Deerlick creeks at three to six hour intervals.

\subsubsection{Results and Discussion}

Suspended sediment yield in each basin was highly variable (Figure 9). Suspended sediment yield increased significantly $(p=0.20)$ following timber harvesting in Wampus Creek (Figure 10). Measured postharvest sediment yield in Wampus Creek was $12 \%$ (range from -10 to $30 \%$ ) higher than predicted by the preharvest regression $\left(r^{2}=0.958, n=11\right)$. 


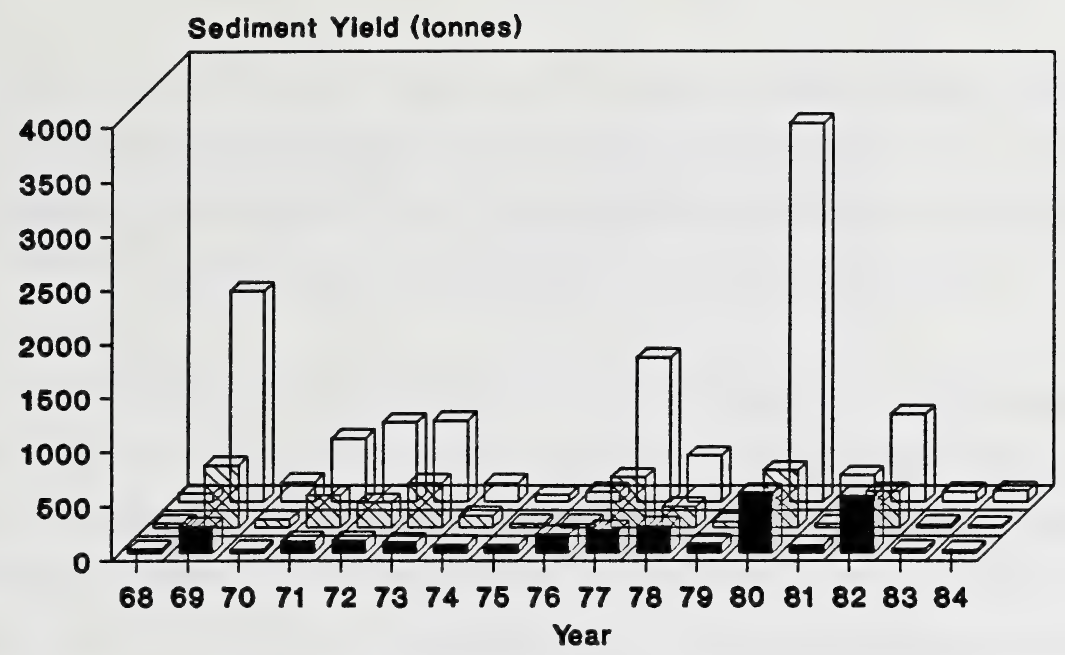

Deerlick Creek $\quad \square$ Eunice Creek $\square$ Wampus Creek

Andres et al. (1987)

Figure 9. Variability in Sediment Yield

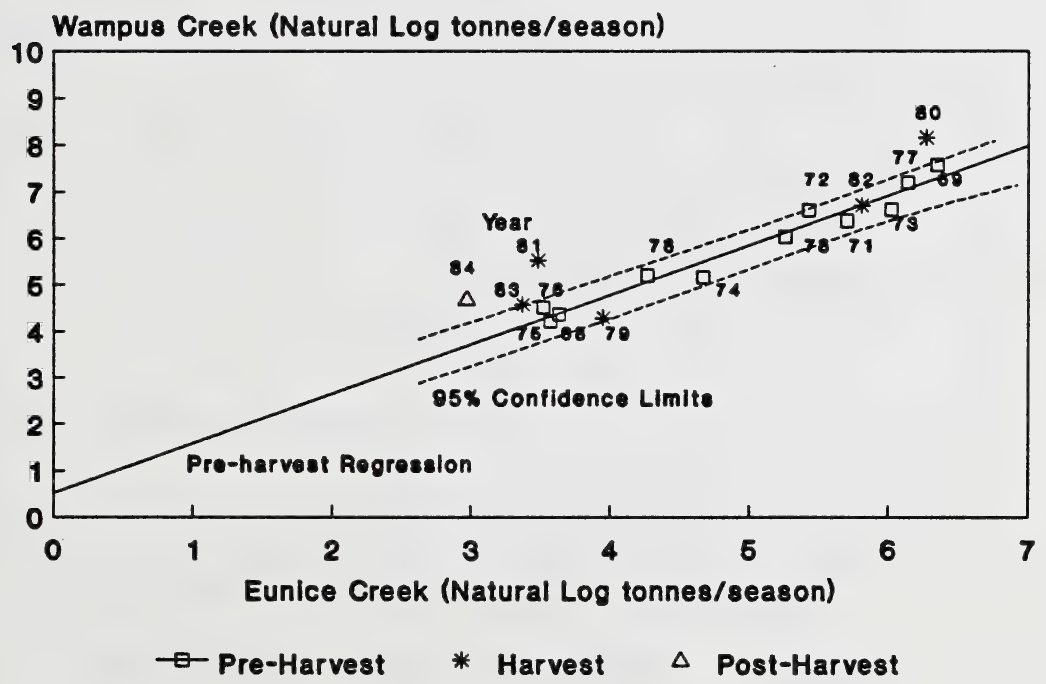

Andres of al. (1987)

Note: Harvest and post-harvest phases are shown for comparison only.

Figure 10. Sediment Yield Between Wampus and Eunice Creeks 
The most noticeable increase (mean of 28\%) were in 1980 and 1984. Basin sediment yield in 1979, 1982 and 1983 fell near or on the preharvest regression curve. This was likely due to low rainfall received in the basin. High sediment yields were also detected in 1969 and 1980. They arose from natural floods unrelated to forest harvesting.

The sediment regime in Deerlick Creek differed from that of Wampus largely because of a major road construction in 1975. Figures $11,12 \mathrm{a}$ and $12 \mathrm{~b}$ illustrates the great impact of the haul road had on the sediment regime. Significant differences $(p=0.05)$ were found between preharvest and road construction and preharvest and postharvest phases. Mean measured sediment yield in the road construction - evaluation phase was $24 \%$ (range from -5 to $52 \%$ ) greater than the predicted preharvest regression $\left(r^{2}=.835, n=7\right)$. The largest impact, with $26 \%$ and 52\% above predicted preharvest levels occurred in 1975 and 1976, respectively. This is attributed to the construction of the haul road. Mean measured sediment yield of the postharvest phase was $19 \%$, with a range of 10 to $26 \%$, greater than the predicted preharvest regression.

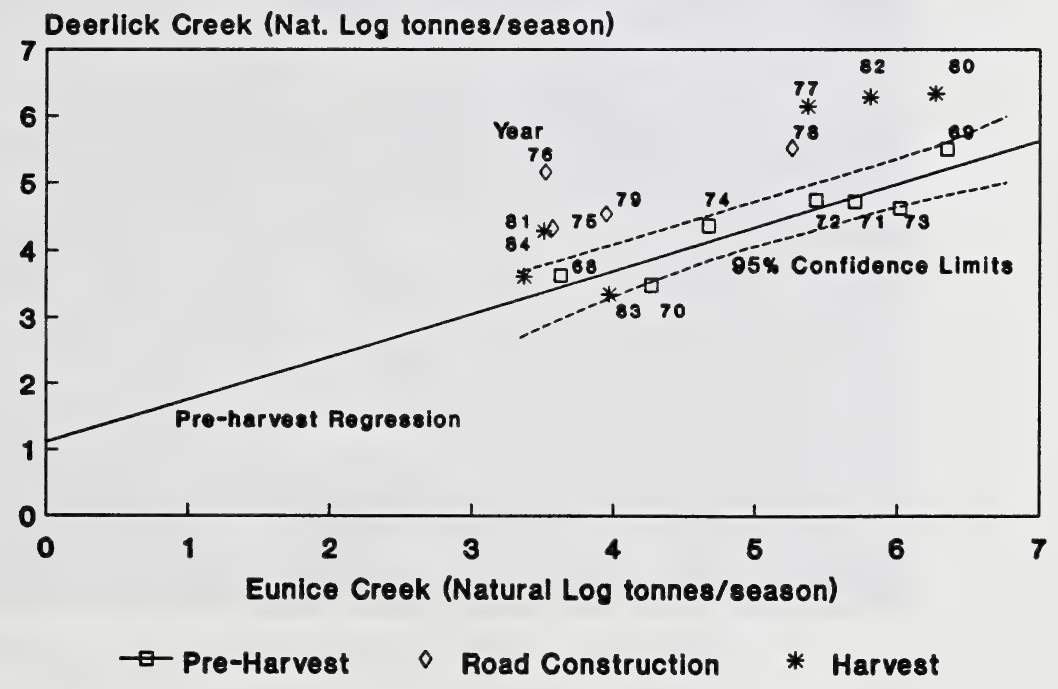

Andres of al. (1987)

Note: Road construction and harvest phases are shown for comparison only.

Figure 11. Sediment Yield Between Deerlick and Eunice Creeks 


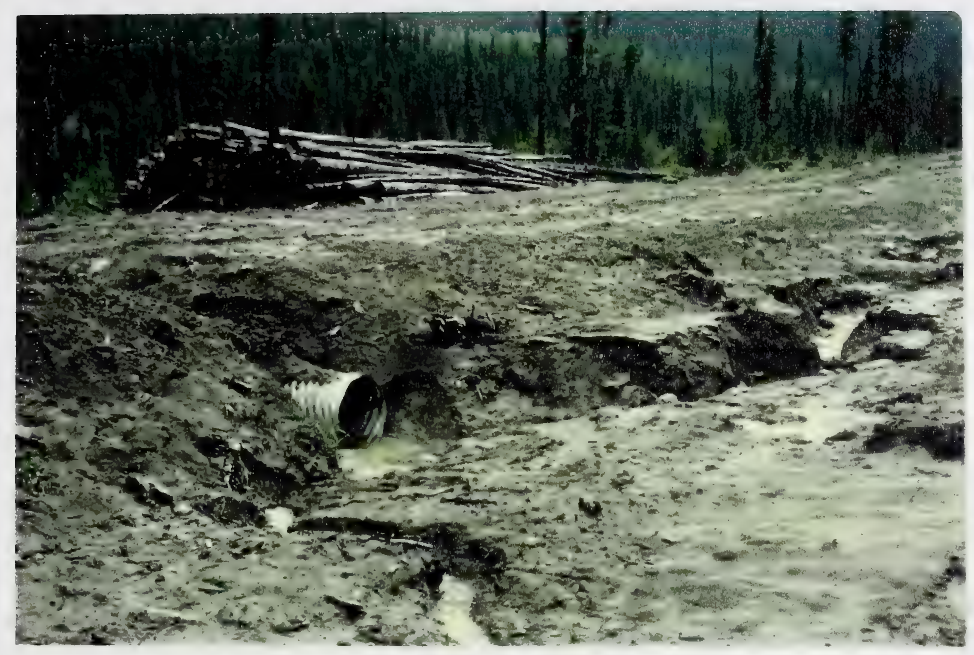

Figure 12a. Haul Road After Construction (1975)

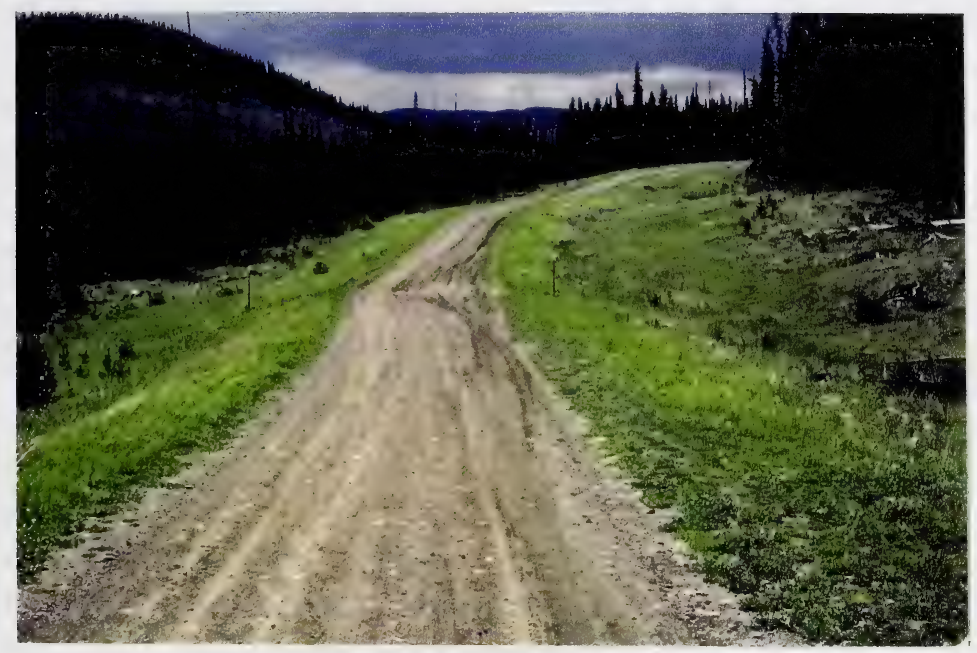

Figure 12b. Haul Road After Stabilization (1985)

Preharvest and postharvest phase seasonal suspended sediment yield ratios (Table 4) were calculated to evaluate the effectiveness of treed buffer strips in preventing sediment from entering streams. Approximately 57 per cent of Deerlick Creek was buffered before 

harvesting and 35 per cent after logging. Fifty-eight per cent of Wampus Creek remained buffered but no buffer strips were left on the cutblocks. Examination of Table 4 suggests Wampus Creek (buffered) produced less sediment than Deerlick Creek (unbuffered). This is further supported by regression analysis previously mentioned. However, it is important to recognize that these results were based on a non-point source sampling at the outlet of each basin. It is also important to recognize that slope length, slope gradient, total area of bare soil exposed and the amount of vegetative cover can influence the amount of sediment that enters a stream channel. Jablonski (1986) surveyed Wampus and Deerlick creeks and documented proper as well as poor logging, road construction, maintenance and reclamation practices. He observed point sources of sediment in buffered and unbuffered cutblocks. He stressed that good forest management practices, rather than the presence or absence of treed buffer strips along cutblocks, was the key to minimizing the amount of sediment entering the stream.

Table 4. Sediment Yield Ratios

\begin{tabular}{lccc}
\hline & Preharvest Phase & Postharvest Phase & \% Change \\
Deerlick/Wampus & 0.161 & 0.258 & 60.2 \\
Wampus/Eunice & 2.595 & 6.036 & 132.6 \\
Deerlick/Eunice & 0.418 & 1.297 & 210.3 \\
\end{tabular}

Point sampling of sediment was conducted in Wampus and Deerlick. Jablonski (1980) and Wasiliew (1986) identified poorly constructed, maintained, and reclaimed stream crossings and access roads through ephemeral draws, tributaries and source areas as the primary source of sediment. Sampling included an ephemeral draw along a haul road (102), a stream crossing, scarified cutblock and a slump along Craig's road. To determine whether the access roads in Tri-Creeks were similar to those within Weldwood's forest management (FMA) area, Jarvis (1984) compared the standards of construction, maintenance and reclamation of access roads and stream crossings within the Tri-Creeks basin with other basins within Weldwood's FMA agreement area. He concluded the construction and maintenance of access roads and stream crossings were similar, however, the reclamation of access roads was more intensive in the Tri-Creeks basin. 
Table 5 shows the range of impacts in 14 storm events in 1985 from four point sources, all associated with harvesting except W-3, within Wampus Creek basin. Sediment loadings for point sources were highly variable, with values ranging from 2 to 50 tonnes/day (above a point source) to 3 to 65 tonnes/day (below a point source). Suspended sediment concentrations were higher immediately below the point source than above it.

Table 5. Sediment Loading at Point Sources in Wampus Creek

Station*

Mean Sediment Load (tonnes/day) Standard Deviation

W-3 downstream

W-3 upstream

W-C downstream

W-C upstream

W-8 downstream

W-8 upstream

W-10 downstream

W-10 upstream

* upstream or downstream of the point source.
33.6

28.9

65.3

50.1

31.0

17.3

2.7

2.0
56.6

45.1

116.8

100.1

57.9

23.0

4.6

3.6

(Wasiliew 1986)

Wasiliew (1986) examined sediment dynamics along Wampus Creek and found evidence of sediment transport and deposition occurring between sampling sites. He found that steeper gradients enhanced stream velocities and decreased the occurrence of sediment deposition while low slope gradients and settling areas increased the occurrence of sediment deposition. The overall slope gradient of stream channels in Tri-Creeks (Wampus Creek at $18.9 \mathrm{~m} / \mathrm{km}$, Deerlick Creek at $25.6 \mathrm{~m} / \mathrm{km}$, and Eunice Creek at $34.9 \mathrm{~m} / \mathrm{km}$ ) is relatively steep, thus providing sufficient stream velocities during large storm events to flush fine materials downstream and consequently leaving coarser material (sand and gravel) in the streambed.

Jablonski (1980) sampled an ephemeral draw crossing a haul road during a storm event. He found that suspended sediment concentration and turbidity changed with distance away 

from a point source in Deerlick Creek basin (Figure 13). Both were highest immediately below the point source and then decreased with distance away from the point source (Jablonski 1980). High suspended sediment concentrations were attributed to a large storm event (27 mm. rainfall) as well as the highly erodible lacustrine soils moving from an ephemeral draw into the stream. Concentrations remained high even a kilometre downstream of the point source. Sampling further than 1 kilometre downstream of the point source was not possible due to the confluence of Deerlick Creek entering the Mcleod River.

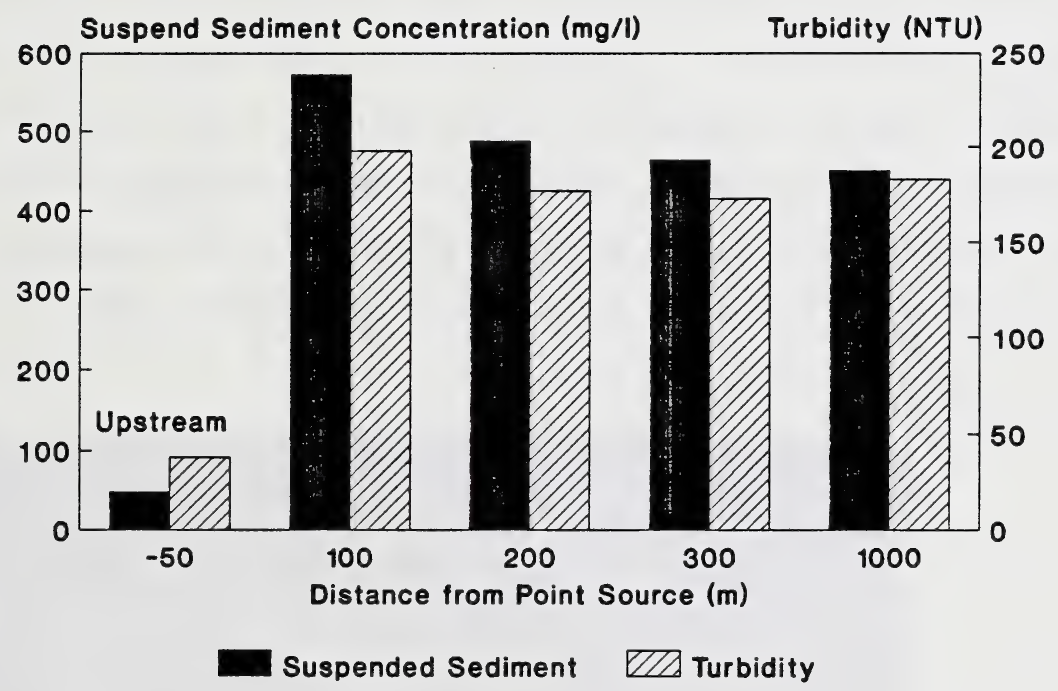

Jablonski (1980)

Figure 13. Suspended Sediment and Turbidity From a Point Source

Seven sediment storm hydrographs for each basin at various phases (preharvest, road construction, harvest and postharvest) were examined. No changes in the sediment storm hydrograph were detected following logging.

Overall, stream crossings, access roads and crossing of source areas and ephemeral draws, were the prime source of sediment entering the stream. These point sources were 

present in both unbuffered and buffered cutblocks. With good logging practices, sediment can be prevented from entering the stream.

\subsection{Water Temperature}

Most foothill streams are cold throughout the year. Mean annual water temperature (1977-78) at Marmot Creek experimental basin in Alberta is $3.2^{\circ} \mathrm{C}$ (Inlands Water Directorate 1982). The mean annual stream temperature prior to harvest at two watershed basins in the Alsea Watershed study located in Oregon's Cascade Range was $10^{\circ} \mathrm{C}$ (Brown and Krygier 1970). Timber harvesting and removal of streamside vegetation (Figure 14) can increase the amount of short wave radiation striking the water surface and in turn increase water temperature. Any increase in temperature can subsequently influence the metabolism of organisms, breakdown of organic matter, dissolved oxygen levels and production of biomass.

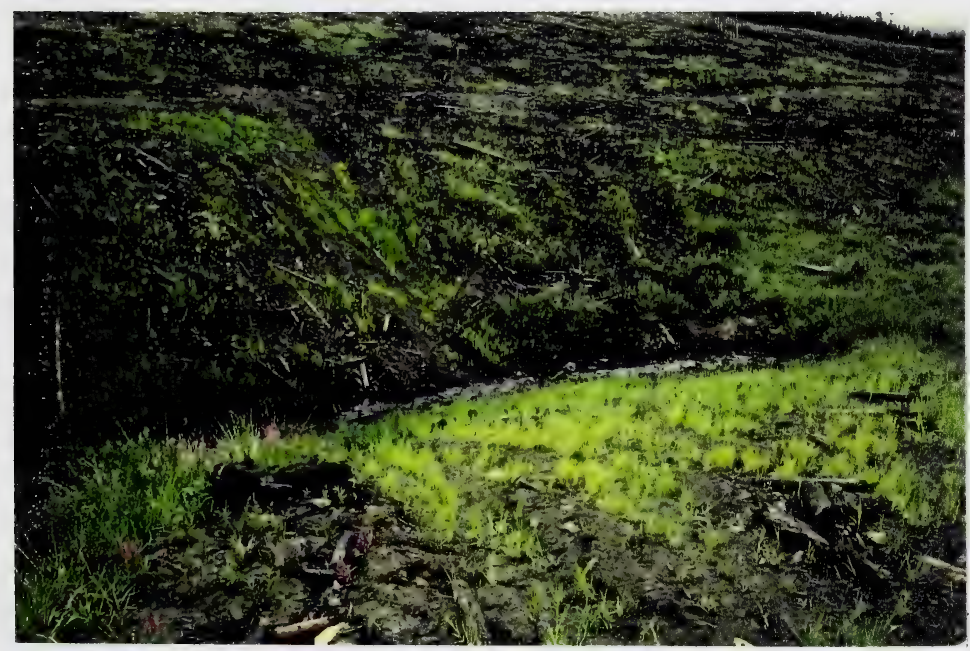

Figure 14. Removal of Streamside Buffer Strip Along Deerlick Creek 



\subsubsection{Objective}

The objective was to determine the impact of removing streamside buffer strips on the thermal regime of surface water.

\section{$\underline{\text { 3.3.2 Methods }}$}

Nygretti chart recorders, located near the confluence of each stream, recorded stream temperature during the open water season of Wampus, Deerlick and Eunice creeks. Additional stream temperature recorders were located above and below clearcut areas. Short wave radiation, air and stream temperatures and stream discharge were also measured in 1985 and 1986. Stream temperatures during the harvest phase were treated as part of the postharvest phase in regression analysis to increase the sample sizes (harvest $\backslash$ postharvest years).

\subsubsection{Results and Discussion}

The streams in Tri-Creeks are cold year-round. They begin to freeze in mid-October and remain ice-covered until May. Complete thaw under the bridge decks varied from early May to mid-June. Warming is slow because streambanks are shaded by vegetation, the position of the sun is low and the climate is cool.

Eunice Creek was the coldest of all three streams throughout the study. Mean stream temperature between May and October was 6.2, 5.4 and $4.3^{\circ} \mathrm{C}$ in Wampus, Deerlick and Eunice creeks respectively. No significant increase in monthly mean water temperature was detected in Wampus Creek following logging. In Deerlick Creek, an increase in monthly mean temperature following logging was detected in the warmest months (July and August).

Significant increases $(p=0.05)$ in maximum water temperature were detected in the treated basins following harvesting. The average difference in mean maximum temperature 

between pre and post harvest condition in Wampus was $1.8 \mathrm{C}^{\circ}$ (range from 0.3 to $2.4 \mathrm{C}^{\circ}$ ) compared to $3.8 \mathrm{C}^{\circ}$ (range from 1.6 to $5.7 \mathrm{C}^{\circ}$ ) in Deerlick Creek. Increases after logging were most evident in the warmest months (July and August), as shown in Table 6 and Figures $15 \mathrm{a}$ and $15 \mathrm{~b}$. Mean maximum temperature during these two months increased $3.0^{\circ} \mathrm{C}$ and $5.4^{\circ} \mathrm{C}$ in Wampus and Deerlick creeks respectively. The largest difference between monthly maximum stream temperature before and after logging was in August; for Wampus and Deerlick creeks, it was 3.4 and $5.7 \mathrm{C}^{\circ}$, respectively. There was also some indication of a smaller increase during June in both treated basins and during September in Deerlick Creek. These results indicate that forest harvesting caused an increase in stream temperature and removal of streamside vegetation magnified the effects. The highest daily maximum stream temperature reached was $21^{\circ} \mathrm{C}$ at Deerlick Creek.

Table 6. Mean Monthly Maximum Stream Temperature (C')

Wampus Creek (buffered)

Preharvest

Postharvest

June

July

August September

12.6

13.5

15.4

16.1

11.5

Deerlick Creek (unbuffered)

Preharvest

Postharvest

11.3

13.4

13.5

9.6

12.9

18.5

19.2

11.6

Eunice Creek (control)

"Preharvest" 1967-1980

"Postharvest" 1981-1985

(Andres et al. 1987) 



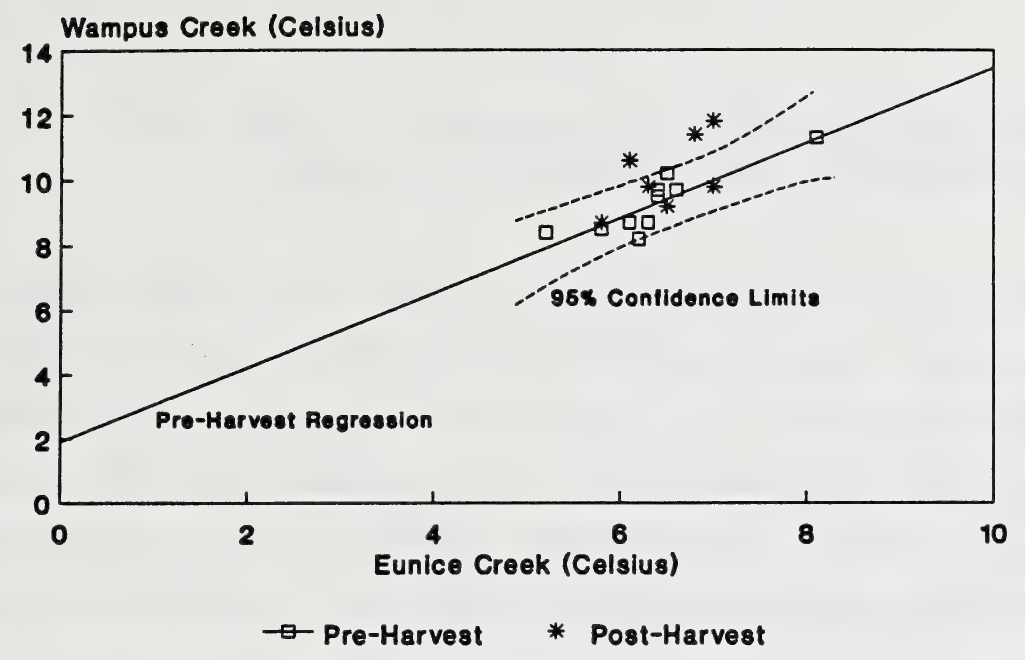

Andres et al. (1887)

Note: Postharvest phase is shown for comparison only.

Figure 15a. Comparison of July Maximum Water Temperature Between Wampus and Eunice Creeks

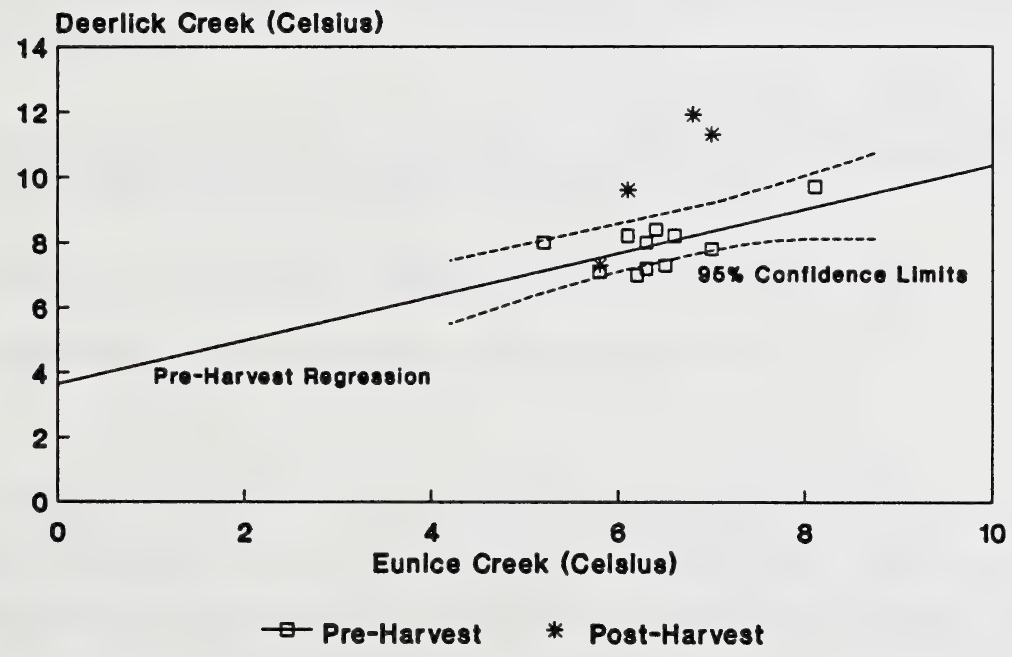

Andres ot al (1987)

Note: Postharvest phase is shown for comparison only.

Figure 15b. Comparison of July Maximum Water Temperature Between Wampus and Eunice Creeks 



\subsection{IMPACT OF TIMBER HARVESTING ON FISHERIES AND BENTHIC INVERTEBRATE POPULATIONS}

Many studies report timber harvesting can potentially alter aquatic environments. Changes can include an increase in the following variables: nutrient export (Brown 1978, Likens et al. 1969), sedimentation (Anderson et al. 1976), water temperature (Brown and Krygier 1970) and streamflow (Swanson and Hillman 1977). These impacts can affect fish populations by altering spawning, development and hatching of eggs, and growth and survival of young fish. These changes may also affect macroinvertebrate populations.

\subsection{Effects of Sedimentation on Benthic Invertebrate Populations}

Benthic macroinvertebrates are a vital food source for many salmonid species. Several studies (McCart and deGraff 1974; Rosenberg and Snow 1975; Rosenberg and Wiens 1975) report stream sedimentation can adversely affect macroinvertebrate populations in the following ways:

1. reduction in light penetration, thus a reduction in or elimination of photosynthesis and subsequent reduction of food production;

2. increase in abrasion of respiratory and excretory organs; and

3. reduction in habitat, species diversity and biomass.

Logging can cause increased sediment deposition, which can alter the benthic (stream bottom dwelling) fauna composition by changing the population structure from one dominated by Ephemeroptera, Plecoptera and Trichoptera to one dominated by Diptera (Chironomidae) (Hynes, 1970). Increased stream velocities can cause scouring of streambeds and subsequent reduction of benthic biota. However, scouring of streambeds can also remove fine materials, leaving coarse material behind. This process provides new habitat for benthic macroinvertebrate recolonization. 



\subsubsection{Objective}

The objective of this study was to determine the effect of point source sedimentation on benthic macroinvertebrate populations.

\subsubsection{Methods}

During the summers of 1977 to 1982, benthic invertebrate surveys were conducted monthly $200 \mathrm{~m}$ above, and 500 and $1200 \mathrm{~m}$ below an emphemeral draw known to contribute sediment into Deerlick Creek. A modified Hess sampler (Hess 1941), supplemented with a basket and multiplate sampler in 1981 and 1982, was used to collect three replicate samples from each station. Species abundance, diversity, richness and biomass were determined. Sediment point source sampling was conducted at the time of the benthic survey to determine sediment loading from the ephemeral draw. Sediment traps were also established to determine sediment deposition at each site. Particle size composition was determined using the Bouyoucos method.

\subsubsection{Results and Discussion}

Although no measurable differences in benthic macroinvetebrate populations above and below a point source were found (Nip 1981, 1982) because the sample size was not sufficient to detect any statistically significant changes. Species abundance and richness were highly variable spatially and temporally during active sediment input from the ephemeral draw.. Total number of organisms ranged from 7 to 158 organisms $/ \mathrm{m}^{2}$ and richness ranged from 6 to 28. Mean species richness and species abundance stabilized at 15 and 23 organisms $/ \mathrm{m}^{2}$ respectively once the disturbance was revegetated. Species diversity was highly variable (ranging from 1.6 to 3.4) throughout the study. This can be attributed to natural seasonal population fluctuations because of egg laying, hatching, emergence and growth.

There was a shift in the composition of fine materials in the sediment traps over time, 

from one dominated by silt and clay to one dominated by sand. Sand increased from 39 to $65 \%$, clay decreased from 24 to $15 \%$ and silt decreased from 37 to $19 \%$ for the period of 1978 to 1982 . Re-establishment of vegetation in the ephemeral draw helped minimize the amount of sediment entering the stream. With fewer fine materials entering the stream, more habitat suited for benthic invertebrates such as mayflies, stoneflies and caddisflies became available. This resulted in recolonization of more suitable habitat and the stabilization of the benthic population. This suggest benthic macroinvertebrate populations can survive a small disturbance such as an ephemeral draw contributing sediment and recover from it upon neutralization of the disturbance.

\subsection{Population Dynamics of Major Salmonid Species}

Forest harvesting can affect fisheries production in many different ways. Hartman and Holtby (1982) and Hartman et al. (1983) summarized the impact of forest harvesting on fisheries production in the Carnation Creek watershed study in British Columbia. They reported that: 1) increased light penetration from removal of streamside canopy resulted in a moderate increase in summer stream temperature and this appears to be beneficial to coho salmon; and 2) nutrient increases were essentially beneficial to production of algae and invertebrates (food source for coho salmon).

Increased stream temperature resulting from removal of riparian vegetation can affect fish survival and growth. Elevated temperatures reduce dissolved oxygen saturation levels, causing increases in respiratory and metabolic rates. Respiration approximately doubles for every $10^{\circ} \mathrm{C}$ rise in temperature (McKee and Wolf 1963). Every species of fish has a maximum tolerable stream temperature. The U.S. Federal Water Pollution Control Administration (1968) reported that the optimum stream temperature for trout growth and reproduction is 13 to $15^{\circ} \mathrm{C}$. They also recommend that increases in stream temperature should not exceed $3^{\circ} \mathrm{C}$ above naturally occurring conditions. Wallace and Strong-Duffin (1985) found that a minor impact on rainbow trout could occur when stream temperatures reaches $22^{\circ} \mathrm{C}$. At $23^{\circ} \mathrm{C}$, it becomes lethal. 

Increased sediment levels can affect fisheries production (Griffith and Walton 1978; Philips 1971). Hynes (1974) reported that two forms of sediment (suspended versus settled Increased suspended sediment and turbidity levels, which reduces light penetration, may decrease primary production and in turn reduce aquatic invertebrate and fish populations. Beschta (1978) found that deposition of silt on spawning gravels affected the ability of dissolved oxygen to penetrate into the spawning gravels. As a result of interstitial gravels covered with silt, eggs may be asphyxiated and fry emergence prevented. Another effect is decreased fry survival after emergence due to decreased escape cover and food supply (Phillips 1971).

Longmore and Stenton (1981) observed that rainbow trout prefer sediment concentrations of less than $10 \mathrm{mg} / \mathrm{l}$. Beak and Associates (1987) reported that concentrations less than $25 \mathrm{mg} / 1$ have no harmful effects for salmonids. However, concentrations between 25 and $80 \mathrm{mg} / \mathrm{l}$ for 24 hours or longer may be tolerated with some restriction in salmonid productivity. Hynes (1973) reported that sediment concentration under $80 \mathrm{mg} / \mathrm{l}$ was unlikely to seriously damage fisheries; however growth rates and abundance may be reduced. Concentrations greater than $400 \mathrm{mg} / 1$ for periods greater than 24 hours will cause a major adverse impact (Beak and Associates 1971). When such increases in suspended sediment concentration does occur, fish have the ability to move away from the areas affected (Hynes 1973).

\subsubsection{Objective}

The objective was to determine whether forest harvesting altered the population dynamics of major salmonid species at Tri-Creeks.

\subsubsection{Methods}

The fisheries program concentrated primarily on rainbow trout and secondarily on mountain whitefish and bull trout. Seven components were investigated in the fisheries 

studies:

1. migratory movement

2. fecundity and egg retention

3. spawning

4. site selection for spawning

5. interstitial water chemistry

6. population density and recruitment and

7. age and growth.

Migratory movement of rainbow trout was assessed by capturing and releasing tagged trout at established sites. Annual fecundity was estimated in several stream reaches from mature female fish prior to spawning. Fish were measured for weight and length. Reconnaisance surveys identified spawning locations and egg pits. Egg pits were excavated to obtain an estimate of egg deposition. Interstitial chemistry (dissolved oxygen, $\mathrm{pH}$ and water temperature) was measured insitu from standpipes driven into the spawning substrate. Composition of spawning gravels was determined from core samples taken near the spawning gravels. Fry emergence was assessed by capturing fry from natural redds. Population estimates were obtained from mark-recapture experiments conducted in August. Detailed methods are described by Sterling (1978, 1980, 1987).

\subsubsection{Results and Discussion}

Small tributaries, such as the streams in Tri-Creeks, are important spawning and brood areas for resident and migratory rainbow trout. Limited numbers of rainbow trout entered from the McLeod River during the spring spawning season to the lower reaches of the Tri-Creeks basin (Dietz 1971; Sterling 1980). Spawning generally occurred in upstream portions of a riffle or riffle-pool transition zones where good interstitial flow occurred. Instream movement of resident rainbow trout was intensive during spawning but localized.

Juvenile bull trout were predominately found in the lower reaches of Eunice Creek but also found in the lower reaches of the other study streams. Immature bull trout remained in the brood stream until approximately age five before they emigrated to the McLeod 

River. Mature bull trout spawned in the lower reaches of Eunice Creek from late August to early September. Mountain whitefish moved into the tributaries during summer to forage and during the fall to spawn.

Spawning and recruitment were highly variable over the study period. No significant change in the quality of spawning substrates occurred following logging. Rainbow trout began spawning in late May to early June when maximum daily water temperature reached $6^{\circ} \mathrm{C}$. Stream temperatures showed a positive correlation with times for peak spawning, egg incubation, peak hatching and fry emergence (i.e. the warmer the water, the shorter the time required). Fry escapment was not significantly different following logging.

Growth rates varied between males and females and between different cohorts. Significant differences in growth of rainbow trout between stream sections were observed. Growth of males and females age two and older were significantly different in lower Wampus Creek. Following logging, only age two males had significantly greater mean size. In upper Wampus Creek, growth of males and females of age five and older was significantly different. Following logging, trout age one, two and three had significantly greater mean size. Differences in growth between males and females in lower Deerlick Creek could not be established since there was an inadequate sample size for older fish. Only age two trout had greater mean size following logging.

Rainbow trout population densities for the upper and lower reaches of each stream in Tri-Creeks (Figures 16 and 17) were variable, peaking in the mid 1970s and mid-1980s. Changes in trout densities over the study period were similar between the lower reaches of all three basins. However, the similarity in changes were less evident between the upper reaches.

Minimum densities were detected before logging commenced, indicating that declines in the late 1970 s and early 1980 s were by factors other than forest harvesting. Trout populations declined in the Deerlick Creek basin between 1975 to 1979. A similar decline 

was detected in Wampus Creek basin and Eunice Creek basin to a lesser degree. The most evident declines in population, were attributed to naturally occurring floods in 1969 and 1980. A continued population decline in upper Wampus Creek following the 1980 flood was not attributed to logging but rather the result of beaver dam encroachment and loss of spawning sites and subsequent poor recruitment. In 1984, the removal of beaver dams before spawning commenced resulted in a significant increase in rainbow trout population density. Following logging, most rainbow trout populations recovered to densities equal to or greater than prelogging levels (Sterling 1978, 1980, 1987).

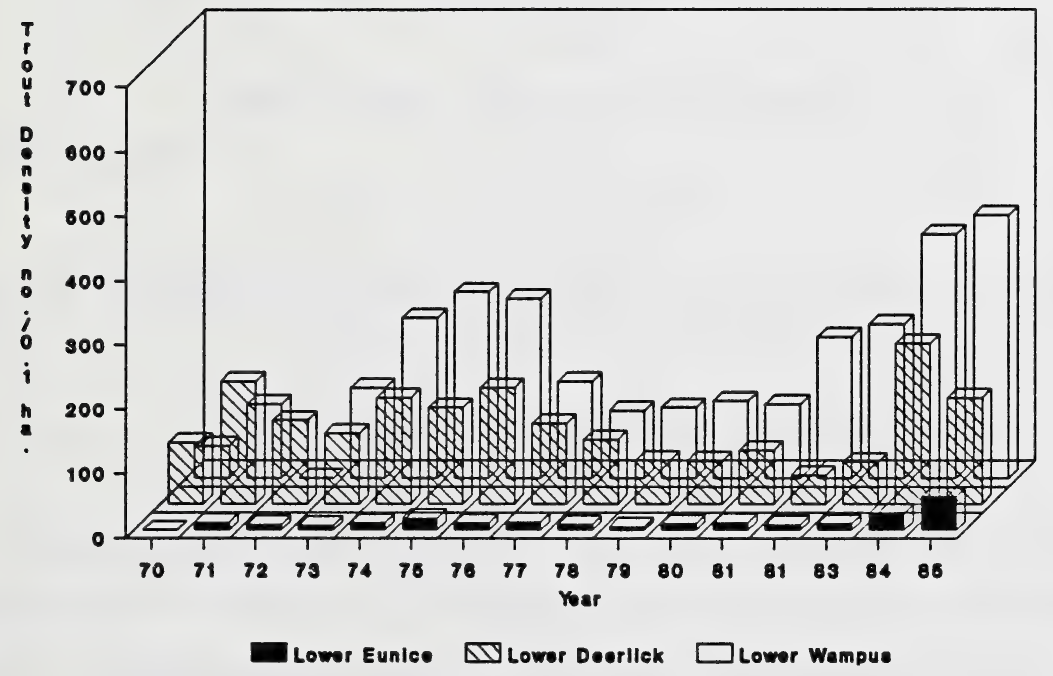

Sterling, G. (pers. comm.)

Figure 16. Rainbow Trout Density in Lower Eunice, Deerlick and Wampus Creeks 



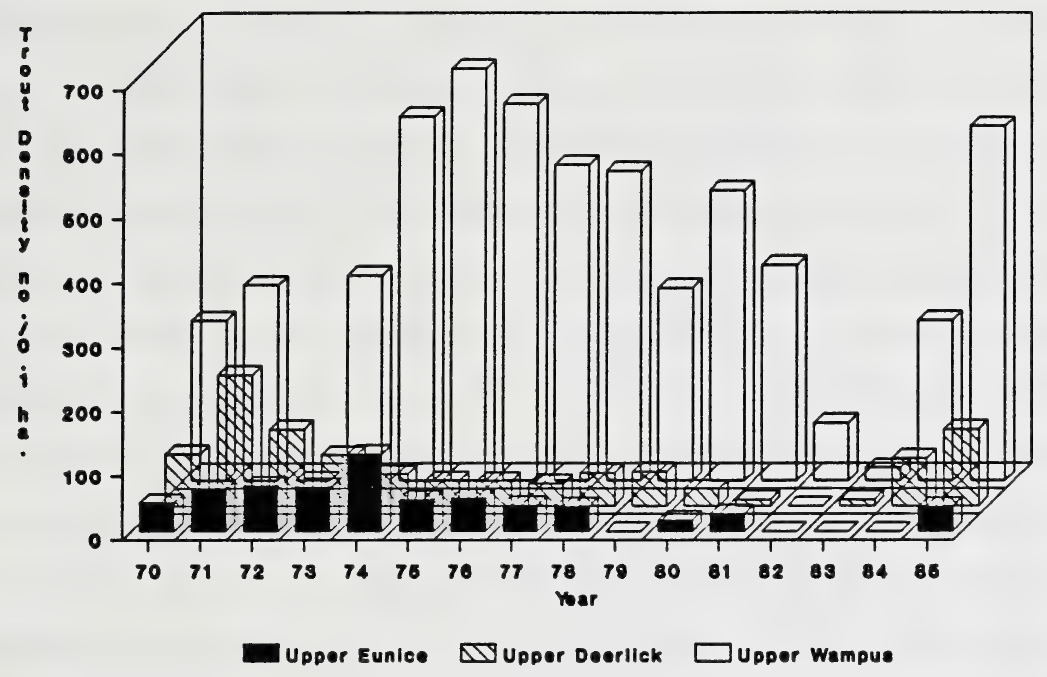

Sterling, G. (pers. comm.)

Figure 17. Rainbow Trout Density in Upper Eunice, Deerlick and Wampus Creeks

\subsection{Impacts of Forest Harvesting on Salmonids}

Changes in streamflow, water quality and stream temperature were detected following logging in the Tri-Creeks basin. The impacts of these changes on salmonid populations were unclear. The naturally high variability of aquatic biota populations and the natural ability of these populations to adapt to environmental perturbations (Hynes 1973; Gammon 1970) have made it difficult to detect changes in populations and attribute such changes to environmental disturbances.

The impact of forest harvesting on a salmonid population may be measured with respect to: 1) spawning success, 2) growth rate and the 3) general population structure. Any changes in spawning success and growth rate will affect the general population structure.

A trend towards increased water yield was detected following logging. For small 

streams such as those in the Tri-Creeks basin, increased water yield during summer low flow conditions would probably be beneficial to stream productivity by providing a larger surface area for aquatic habitat. However, extremely high flow conditions may alter the structure and composition of the streambed. Critical flow was defined as the flow at which spawning substrate began to move. This became critically important during the salmonid incubation period. Any periods of high streamflow before the incubation period, such as spring runoff and storm events, provided sufficiently high streamflows to cleanse the streambed surface (utilized for spawning). However, the critical flow in the study area was $0.54 \mathrm{~m}^{3} / \mathrm{sec}$ and was exceeded 30 per cent of the time during the incubation period. These high flows can cause scouring of the streambed and consequently limited fry escapement. Sterling (1990) found that rainbow trout yearling abundance in the Tri-Creeks experimental watershed was significantly inversely correlated with streamflow exceeding the critical flow during the incubation period.

Due to the absence of winter flow measurements, the effect of streamflows on pool volumes could not be defined. However, pool volumes, although not measured throughout the study, appeared to be sufficient for fish overwintering habitat in all stream reaches except those in upper Eunice Creek.

Changes in water quality following harvesting were observed in the Tri-Creeks watershed. The changes could not be clearly attributable to forest harvesting, however, they did appear to increase stream primary productivity. Although this was not quantitatively documented, field observations showed increased algal productivity only in the logged basins during the post-harvest period. In nutrient poor streams such as those found in Tri-Creeks, a small amount of nutrient export into the stream channel can be beneficial to stream productivity.

The most pronounced change in water quality was an increase in suspended sediment loading into the stream. However, sediment deposition did not increase as a result of increased sediment loads (Sterling 1987; Andres et al 1987). Mean Fredle indices, a 

measure of spawning substrate quality as defined by particle size diameter and weight (Platts et al 1983) improved slightly but not significantly different following logging.

Other water quality parameters measured in the spawning gravels include dissolved oxygen and $\mathrm{pH}$. Dissolved oxygen in interstitial gravels was significantly lower $(\mathrm{p}<0.001)$ following logging. Mean oxygen saturation was 97 (preharvest) and 87 (postharvest) per cent in lower Wampus Creek and 95 (preharvest) and 74 (postharvest) per cent in lower Deerlick Creek. The reduction was not correlated with substrate composition nor increased stream temperature and did not affect egg incubation and fry emergence. Interstitial $\mathrm{pH}$ was not significantly different following harvest (Sterling 1987).

A significant increase in mean monthly maximum stream temperature was observed in the logged basins. With the cool continental climate, it is unlikely that stream temperatures could rise high enough for sufficient long periods to harm salmonids. The highest recorded daily maximum stream temperature of $21^{\circ} \mathrm{C}$ in Deerlick Creek did not exceed the maximum tolerable limit for rainbow trout.

Increased maximum stream temperature helped shorten the time period required for achieving peak spawning, egg incubation, peak hatching and fry emergence. This can be beneficial to fry. Similar correlations were found in the Carnation Creek experimental watershed. Hartman and Holtby (1982) found that early fry emergence would be beneficial by providing more time to feed and to grow before overwintering commenced. This consequently allowed the fry to enter their first winter as larger fish, improving their overwintering survival (Hartman et al 1983).

Increased fish growth rate could not be solely attributed to increased stream temperatures following logging. However, it may result from increased primary production arising from increased stream temperature and/or increased nutrient export following logging. Although primary production was not quantified in this study, an increase in algal production was similar to those observed in the Carnation Creek experimental watershed. 
The increase in stream temperature and nutrient export following logging directly influenced the production of algae in the stream and, indirectly, benthic macroinvertebrate production. De Leeuw (1981) reported that these changes following logging had the potential to contribute to increased growth rates in trout.

In summary, the changes in streamflow, water quality and stream temperature did not appear to adversely affect salmonid populations. Spawning success as measured by fry escapement (Table 7), was not significantly different following logging.

Table 7. Percent Fry Escapement

\section{Wampus Creek}

Preharvest: $41 \pm 27.6(n=3)$

Postharvest: $32 \pm 20.5(n=4)$
Deerlick Creek

$27.8 \pm 39.8(n=6)$

$60 \pm 69(n=2)$

(Sterling, 1986)

Fish growth increased for some age classes following logging. Declines in salmonid population densities, unrelated to forest harvesting, recovered to preharvest levels rapidly. These changes suggest forest harvesting did not cause deterioration of salmonid habitat. However, it does suggest that forest harvesting practices must continue to minimize or guard against creation of unsuitable conditions for salmonid populations and improve on its practices wherever possible. 



\subsection{FOREST MANAGEMENT IMPLICATIONS}

An objective of the Tri-Creeks study was to evaluate the effectiveness of the Alberta Forest Service harvesting groundrules, established for the (formerly) North West Pulp and Power Co. Forest Management Agreement (consolidated version, Schultz and Co. Ltd., 1973) area, in protecting the the watershed and the aquatic environment. Since there are no guidelines in the current edition of the Alberta Timber Harvest Planning and Operating Ground Rules (Alberta Forestry, Lands and Wildlife, 1986) outlining acceptable changes to water quality, timing and quantity following timber harvesting, the evaluation was difficult.

The Tri-Creeks study showed sediment entering the stream channel from point sources. Access roads crossing source areas, poor road locations, stream crossings, improper drainage of right-of-way, poor abandonment practices for roads and stream crossings, and scarification practices resulted in sediment being transported into the stream channel. Erosion is inevitable but it could have been minimized by better road construction, maintenance and reclamation practices.

Several factors contributed to the increase in sediment and turbidity levels following harvesting in the Tri-Creeks basin. For ground rules to be successful, they must be understood and applied in an effective manner. In reviewing this study, problems in which ground rules (consolidated version, Schultz and Co. Ltd., 1973) were applied, implemented, adhered and enforced and how the results were evaluated were identified. The problems are discussed below.

1. Land use disturbance in buffer areas including construction of roads and removal of forest canopy within $30 \mathrm{~m}$ of the stream's high water mark is not permitted except where removal of forest cover up to the high water mark is approved. This was not always adhered to nor enforced. With proper and careful planning and operation of equipment such that the organic or duff layer is not disturbed, trees can be harvested along the streamside without causing a significant amount of sediment to enter the stream channel. 

2. a) Proper drainage shall be incorporated into road construction, to minimize erosion on the road surface, on the cut and fill slopes or in the ditches.

b) All roads shall be maintained in such a manner to allow drainage and to prevent erosion.

c) Roads which will not be used will either be "put to bed" in a manner which will minimize erosion or given maintenance for drainage and erosion prevention so that no significant erosion will occur.

The above groundrules, outlining proper road construction and maintenance, were either not always adhered to or not enforced and resulted in transport of sediment into the stream channel. Proper planning of road locations, minimizing the number of crossings of source areas and ephemeral draws and proper maintenance of these roads could have prevented or minimized sediment entering the stream channel.

3. All stream crossings and bridges shall be located and constructed so as to cause a minimum or erosion damage and sediment deposit in stream chnnels and corrective measures are to be implemented as soon as possible. Erosion control measures at stream crossings were either not always implemented, not effective or not enforced during and after construction.

4. Site inspection often resulted in conflicting opinions about whether an erosion problem existed. Legislated inspection standards for evaluating the effectiveness of erosion control measures and reclamation practices are not available. At present, the Erosion Potential Index (EPI) (Anderson and Anderson 1987) provides a method of determining whether a site requires reclamation work. However, this index has not been tested for Alberta conditions nor is it in present legislation. It is recommended that techniques such as the EPI and standards controlling suspended sediment concentrations below point sources be developed and implemented into future revisions of the harvesting ground rules. If the EPI is to be used, it is recommended that the interpretations of the EPI be evaluated for different soil conditions in conjunction with a suspended sediment sampling program of point sources.

5. Erosion control measures along rights-of-way must be implemented to prevent sediment from entering the stream channel. This groundrule was not always followed nor enforced.

The Tri-Creeks study demonstrated buffer zones in a harvesting operation can be managed effectively. Winter harvesting operations conducted on frozen soil in Tri-Creeks appeared successful in minimizing soil erosion and streambank disintegration even in areas without treed buffer strips. Point sources of sediment occurred in buffered and non-buffered 

cutblocks. With good logging practices on buffered and non-buffered watersheds, sediment entering the stream channel can be minimized. Deerlick Creek experienced an increase in stream temperature following removal of streamside canopy. Such an increase appeared to have a positive effect on fish populations.

A preliminary study indicated forest harvesting can alter the amount and distribution of snow within a clearcut. Uneven snow cover in cutblock no. 13 suggests that there could be localized soil moisture deficit problems in the spring and summer. A regeneration survey conducted in this cutblock indicated a stocking level of 59 per cent. Studies have shown that tree seedling germination and establishment can be reduced by moisture stress and associated high surface soil temperatures. Further research is needed to determine the influence of cutblock size, aspect, topography and wind on the distribution of snow and its effects on soil moisture and subsequent tree seedling survival. New forest management practices, such as site preparation methods and cutblock designs, would have to be developed and implemented should the problem be significant.

The Tri-Creeks study demonstrated timber harvesting, water and the fisheries resource of a watershed are linked. The study also demonstrated all three resources must be considered in the planning and forest harvesting process if they are to be jointly managed. Forest harvesting practices conducted at Tri-Creeks did not appear to have a negative impact on the salmonid population.

In evaluating the current Alberta Timber Harvest Planning and Operating Ground Rules (Alberta Forestry, Lands and Wildlife, 1986), they were found to be overall more stringent in protecting the watershed than the groundrules for the Northwest Pulp and Power Ltd. Forest Management Agreement. The current edition has also taken an integrated resource approach, addressing the concerns of watershed management, reforestation and reclamation, timber management and fish and wildlife. Recent guidelines for stream crossings, road construction and erosion control (Stream Crossing Guidelines: Operational Guidelines for Industry (Fisher et. al. 1985), Resource Road Planning 

Guidelines (Fisher 1982) and The Resource Handbook: Operating Guidelines for Industry (1984)) further encourages better forest management practices. Thus, watersheds with similar physiographic and hydrometeorological characteristics to those of Tri-Creeks can be expected to experience similar and possibly fewer impacts than those in Tri-Creeks in the first pass of cutting if current harvesting ground rules and guidelines are followed and enforced. 


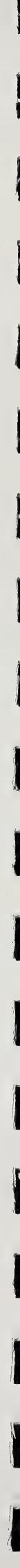




\subsection{SUMMARY}

The following is a brief summary of the results of the Tri-Creeks Experimental Watershed study. The information presented is generally based on a paired basin approach. Due to a short (maximum of three years) postharvest monitoring phase, the harvest and postharvest phases were combined into a single "postharvest" phase to increase the size of the "postharvest" database. In addition, the sampling frequency of various variables was much greater during the postharvest phase than those in other study phases. The various impacts following harvesting presented below should be taken in context with each appropriate section of this report.

1. Timber harvesting had no measurable impact on the fisheries. Natural flooding, not related to logging, had a greater negative impact on the fisheries than timber harvesting. The rainbow trout population in Tri-Creeks was highly variable. Changes in trout densities over the study period were similar between the lower reaches of all three basins. Minimum densities were detected before logging commenced, indicating that the decline in the late 1970's and early 1980's were by factors other than forest harvesting. Warmer stream temperatures were correlated with shorter periods for peak spawning, hatching and fry emergence. An increase in growth of 1,2 and 3 year old rainbow trout was detected following logging. No deterioration in spawning habitat was detected following logging.

2. The removal of riparian vegetation (buffer strips) resulted in a significant increase in mean monthly maximum stream temperature. The increase was most prominent in July and August. Smaller increases in stream temperature were also detected in the treated basin without removing the buffer strips, but it appeared removal of riparian vegetation enhanced the warming of the streams. Due to the naturally cold temperatures of these streams, the increases appeared to be beneficial to fish populations. Point sources of sediment occurred on buffered and non-buffered watersheds. Treed buffer strips did 


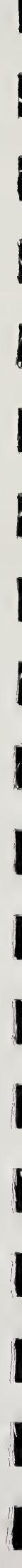


not necessarily prevent sediment from entering the stream. With good logging practices on buffered and non-buffered watersheds, sediment entering the stream channel can be minimized.

3. No significant differences in water yield between the unlogged and logged basins were observed following harvesting. However, the trend showed an increase of 7 and 22 per cent in water yield during the ice-free period in Wampus and Deerlick basin respectively.

4. Stream base flow appeared to be primarily derived from groundwater discharge. No significant changes in the shallow and intermediate groundwater systems were detected following logging. However, any impact on the shallow groundwater system as a result of logging will affect streamflow and stream water quality.

5. Preliminary results showed snow accumulation in a cutblock was greater than in the adjacent forest. However, distribution of snow in the cutblock was highly variable with occasional spots where accumulated water equivalent was less than $5 \mathrm{~cm}$. The distribution appeared to be influenced by topography, slash accumulation and wind. The snow pack in the cutblock disappeared earlier than that in the residual forest. No attempt was made to verify these results for the entire basin, however, cutblock and topographic conditions throughout the basin are similar. Similar results were observed in a cutblock with similar topographic conditions outside the study area. Further research is needed to determine the influences of cutblock size, aspect, topography and wind on the distribution of snow and its effects on soil moisture and subsequent tree seedling survival.

6. Suspended sediment yield increased significantly during and following road construction in Deerlick Creek basin and following forest harvesting in both basins. Point sources such as stream crossings and access roads crossing ephemeral draws and source areas were the main contributors of sediment entering stream channels. Higher sediment 


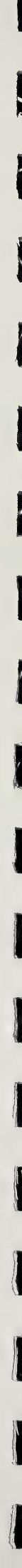


yields were detected during storms at sites below a point source when compared to sites above the point source. Inadequate reclamation and revegetation of abandoned roads and stream crossings resulted in increased sediment downstream of the point source. It is best to minimize soil erosion to guard against deterioration of aquatic biota habitat conditions and creation of lethal conditions.

7. There was a significant increase in total phosphate in the logged basins following harvesting. Significant decreases in $\mathrm{pH}$, nitrate-nitrite and ammonia were observed in all three basins during the post-harvest phase, thus could not be attributed to harvesting. These changes were small in magnitude and did not caused a deterioration in water quality following harvesting. Harvesting appeared to cause a small increase in stream nutrient enrichment as observed by an increase in primary productivity in the logged basins only.

8. Continued recognition is needed of the importance of forest harvesting ground rules and operating conditions and their application, implementation, enforcement and postharvest evaluation. They are essential to minimize the impacts of forest harvesting on the aquatic environment and the watershed. Every component of the forest harvesting process pertaining to the ground rules and operating conditions must be observed if these ground rules and operating conditions are to be effective. Forest harvesting groundrules must and will continue to evolve to foster better forest managment practices.

9. In order to manage the watershed and its resources (timber, water, wildlife and fisheries), land managers must consider the impact of one resource on another. 


\subsection{CONCLUSION}

The Tri-Creeks Experimental Watershed research program was able to fulfill its objectives with varying degrees of success. The post-harvest evaluation period, intended to span five years, was limited to a maximum of 3 years. Impacts which take time to develop or are subtle and difficult to detect may not have been detected in such a short time period. Similarly, the recovery of areas affected by harvesting to pre-disturbance levels may not have been observed. Monitoring the watershed for the intended five years and preferably, longer would have provided both more time to detect these impacts and a larger data set for statistical analysis. Nevertheless, the observed changes were generally similar to those reported elsewhere in Alberta, Canada and the United States.

In conclusion, harvesting, as applied to a first pass cut, was done with no detectable negative impact to the salmonid population of the Tri-Creeks basin. The long term impact from the initial cut, the impact from a second cut and the probability of watershed recovery to preharvest conditions will remain unknown unless further investigations occur. 


\section{LITERATURE CITED}

Alberta Environmental Centre. 1980. Manual for Chemical Analysis of Water and Wastes. Alberta Environmental Centre. Vegreville, Alberta.

Alberta Forestry, Lands and Wildlife, Forest Service. 1986 Alberta Timber Harvest Planning and Operating Ground Rules.

American Water and Wastewater Association and Water Pollution Control Federation. 1966. Standard Methods for the Examination of Water and Wastewater. 13th Ed. American Public Health Association. Washington, D.C.

Anderson, P and R.A. Anderson. 1987. Erosion Potential Index: A Method for Evaluating Sheet Erosion at Stream Crossings. Alta. For. Lands and Wildlife. ENR Report T/137.

Anderson, H.W., M.D. Hoover and K.G. Reinhart. 1976. Forests and Water: Effects of Forest Management on Floods, Sedimentation and Water Supply. U.S.D.A. Forest Service General Technical Report PSW-18.

Andres, D., G. Van Der Vinne and G. Sterenberg. 1987. Hydrologic, Hydrogeologic, Thermal, Sediment and Channel Regimes of the Tri-Creeks Experimental Basin. Alta. Res. Counc. Rep. No. SWE-87/01. Vol. 1. 418 pp.

Archibald, J.H. 1987. Forest Site Classification of the Tri-Creeks Study Area. Alberta Forestry, Lands and Wildlife, Resource Evaluation and Planning Division, Edmonton. In-house document.

Bates, C.G. and A.J. Henry. 1928. Forest and Streamflow Experiment at Wagon Wheel Gap, Colorado. Mon. Weather Rev. Suppl. 30.

Beak Associates Consulting Ltd. 1987. Review of the Scientific Basis of Water Quality Criteria for the East Slopes Foothills of Alberta. Prepared for the Mountain and Foothills Reclamation Research Program, Hydrology Subcommittee. 46 pp.

Beschta, R.L. 1978. Long Term Patterns of Sediment Production Following Road Construction in the Oregon Coast Range. Wat. Resources Res. Vol. 14, No. 6: 1011-1016.

Bosh, J. M. and J.D. Hewlett. 1982 A Review of Catchment Experiments to Determine the Effects of Vegetation Changes on Water Yield and Evapotranspiration. J. of Hydrol. 55: 3-23. 
Brown, G.W. 1978 Forestry and Water Quality. School of Forestry, Oregon State University. Corvallis, Oregon.

Brown, G.W. and J.T. Krygier. 1970. Effects of Clearcutting on Stream Temperature. Water Resour. Res. 6:1133-1140.

Burns, J.W. 1972. Some Effects of Logging and Associated Road Construction on Northern California Streams. In: Transactions of the American Fisheries Society. 101 (1)

Cairns, J., Jr., J.S. Crossman, K.L. Dickson and E.L. Herricks. 1971. The Recovery of Damaged Streams. Assoc. of Southwestern Biologists Bull. 18:79-106.

Currie, D.V. 1969. Hydrogeology of Tri-Creeks Basin, Alta. MSc. Thesis, Dept. of Geology, Univ. of Alberta, Edmonton.

De Leeuw, D. 1981. The Effects of Logging on Benthic Invertebrate Stream Drift and Trout Growth Rates in Two Small West Coast Vancouver Island Streams. MSc. Thesis. Univ. of Victoria, Dept. of Biology. 353 pp.

Dietz, K, 1971. The fish populations of three streams in the foothills of Alberta. MSc Thesis. Univ. of Alberta. Edmonton, Alberta.

Dumanski, J., M. Macyk, C. Veauvy and J. Lindsay. 1972. Soil Survey and Land Evaluation of the Hinton-Edson Area, Alberta. Rep. No. 31. Research Council of Alberta.

Dunne, T. and L.B. Leopold. 1978. Water in Environmental Planning. W.H. Freeman and Co., San Francisco.

Fisher, G.L. 1982. Resource Road Planning Guidelines for the Green Area of Alberta. Alta. Ener. and Nat. Res., Alta. For. Serv.

Fisher, G.L., A.G.H. Locke and B.C. Northey. 1985. Stream Crossing Guidelines: Operational Guidelines for Industry. Alta. Ener. and Nat. Res..

Fredrickensen, R.L. 1970. Erosion and Sedimentation Following Road Construction and Timber Harvest on Unstable Soils in Three Small Western Oregon Watersheds. U.S.D.A. Forest Serv. Res. Pap. NW-104. 15 pp.

Gammon, J.R. 1970. The Effect of Inorganic Sediment on Stream Biota. U.S. Environ. Protect. Agency. Water Pollut. Control Res. 18050 DWC 12/70. 141 pp. 
Gosz, J. R., G.E. Likens and F.H. Bormann. 1972. Nutrient Content of Litter Fall on the Hubbard Brook Experimental Forest, New Hampshire. Ecology 53:769-784.

Griffiths, W.H. and B.D. Walton. 1978. The Effects of Sedimentation on the Aquatic Biota. Prep. for the Alberta Oil Sands Environmental Reserch Program by Renewable Resources Consulting Ltd. AOSERP Rep. 35.86 pp.

Hartman, G.F., J.C. Scrivener, M.J. Brownlee and D.C. Morrison. 1983. Fish Habitat Protection and Planning for Forest Harvesting in Coastal Streams in British Columbia: Some Research and Management Implications. Can. Indus. Rep. of Fish. and Aquat. Sci. No. 143 Gov. of Can. Fish. and Oceans.

Hartman, G.F. and L.B. Holtby. 1982. An Overview of Some Biophysical Determinants of Fish Population Responses to Logging in Carnation Creek, British Columbia. In: Proceedings of the Carnation Creek Workshop, A 10 Year Review. G. Hartman, Ed. Malaspina College, Nanaimo, B.C. Feb. 24-26, 1982.

Hess, A.D. 1941. New Limnological Sampling Equipment. Limno. Soc. Amer. Spec. Publ. 6:1-5.

Hewlett, J.D. 1979. Forest Water Quality: An Experiment in Harvesting and Regenerating Piedmont Forest. Georgia Forest Research Paper. School of Forest Resources, Univ. of Georgia, Athens, Georgia.

Hewlett, J.D. and A.R. Hibbert. 1967. Factors Affecting the Response of Watersheds to Precipitation in Humid Areas. pp. 213-224 In: W.E. Sopper and H.W. Lull (eds). Proc. Int. Symp. on For. Hydrol. Pergamon Press, Oxford, England.

Hibbert, A.R. 1967. Forest Treatment Effects on Water Yields. pp. 527-543 In: W.E. Sopper and H.W. Lulls (eds.). Proc. Int. Symp. on Forest Hydrology. Pergamon Press, Oxford, England.

Hornbeck, J.W., C.W. Martin, R.S. Pierce, F.H. Bormann, G.E.Likens and J.S. Eaton. 1986. Clearcutting Northern Hardwoods: Effects on Hydrologic and Nutrient Ion Budgets. For. Sci. 32 (2):667-686.

Hudson, H.R., G.M. Greenlee and R.W. Howitt. 1985. Soils and Soil Erosion in the Tri-Creeks Experimental Watershed, Alberta. Alberta Research Council, Rep. No. SWE 85/08. Civil Engineering Dept., Edmonton.

Hynes, H.B.N. 1972. The Ecology of Running Waters. University of Toronto Press. Toronto, Ontario. 


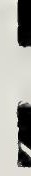


Hynes, H.B.N. 1973. The Effects of Sediment on the Biota in Running Waters. In: Proc. Can. Hydrol. Symp., Fluvial Processes and Sedimentation 9: 652-663. Univ. of Alta. Inland Waters Directorate, Dept. of Environ.

Hynes, H.B.N. 1974. The Biology of Polluted Waters. University of Toronto Press. Toronto, Ontario.

Inlands Water Directorate. 1982. Detailed Surface Water Quality Data. Western and Northern Region. Water Quality Branch, Environment Canada.

Jablonski, P.D. 1978. The Tri-Creeks Watershed: A Study into the Effects of Logging on the Physical, Chemical and Biotic Conditions of Three Alberta Eastslope Streams. The Tri-Creeks Watershed Study Rep. No. 1. Alta. Ener. and Nat. Res., Forest Land Use Branch.

Jablonski, P.D. 1978. Mesoclimate of the Tri-Creeks Region. The Tri-Creeks Watershed Study Rep. No. 3. Alta. Ener. and Nat. Res., Forest Land Use Branch.

Jablonski, P.D. 1980. Pretreatment Water Quality of the Tri-Creeks Experimental Watershed. The Tri-Creeks Watershed Rep. 7. Alta. Ener. and Nat. Res., Forest Land Use Branch.

Jablonski, P.D. 1986 Tri-Creeks: Documentation of the Timber Harvesting Operation From a Watershed Management Perspective. Alta. Ener. and Nat. Res., Forest Land Use Branch. In-house document.

Jarvis, J. 1984. Final Harvesting and Silviculture Report for the Tri-Creeks Experimental Watershed. Alta. Forestry Lands and Wildlife, Alberta Forest Service, Edson, Alberta. In-house document.

Lane, W.L. 1975. Extraction of Information on Inorganic Water Quality. Hydrology Paper No. 73. Colorado State University, Fort Collins, Colorado.

Leaf, C.F. 1975. Watershed Management in the Rocky Mountain Subalpine Zone: the Status of our Knowledge. U.S. Dept. Agric. Forest Service, Rocky Mt. For. Rang.Exp. Stn., Fort Collins, Colorado. Res. Pap. RM-137.

Likens, G.E., F.H. Bormann, N.M. Johnson, D.W. Fisher and R.S. Pierce. 1969. Effects of Forest Cutting and Herbicide Treatment on Nutrient Budgets in the Hubbard Brook Watershed Ecosystem. Northern Forest Exp. Station, U.S. Forest Service, Dept. of Agriculture, Durham, New Hampshire. 
Longmore, C. A and C.E. Stenton. 1981. The Fish and Fisheries of the South Saskatchewan River Basin: Their Status and Environmental Requirements. Alta. Environ., Planning Div. 292 pp.

McCart, P. and D. deGraff. 1974. Effects of Disturbance on the Benthic Fauna of Small Streams in the Vicinity of Norman Wells, N.W.T. Can. Arctic Gas. Bio. Rep. Ser. Vol. 15. Chapt. IV. 28 pp.

McKee, J.E. and H.W. Wolf. 1963. Water Quality Criteria. Resources Agency of California, State Water Control Bd. Sacramento, Calif. Pub. No. 3-A.

Nip, A. M.-K. 1981. Deerlick Creek Benthic Faunal Survey, 1977-1980. Alta. Ener. and Nat. Res., Forest Land Use Branch. In-house document.

Nip, A.M.-K. 1982. Use of Artificial Substrate Samplers in Biological Monitoring of the Aquatic Environment. Alta. Ener. and Nat. Res., Forest Land Use Branch. In-house document.

Nip, A.M.-K.and R. Swanson. 1985. Snow Retention in a Large Cutblock. In: Proc. Snow Property Measurement Workshop. Nat. Res. Counc., Assoc. Commit. on Geotechnical Res. Tech. Memo. 140. 524 pp.

Nip, A.M.-K. 1989. The Applicability of W.R.E.N.S.S., a Water Yield Procedure, to the Tri-Creeks Experimental Watershed. Alta. Forestry, Lands and Wildlife, Forest Research Branch. In-house document.

Olson, R. and R. Hastings. 1989. The Climate of Tri-Creeks Experimental Watershed. Environmental Climate Services. Edmonton, Alberta. Prepared for Alta. Forestry, Lands and Wildlife, Forest Research Branch. In-house document.

Penman, H.L. 1956. Estimating Evaporation. EOS, American GeophysicalUnion Transactions, vol. 31, pp 43-50.

Philips, R.W. 1971. Effects of Sediment on the Gravel Environment and Fish Production. In: J. Morris (ed.) Proc. Forest Land Uses and Stream Environment. Oregon State Univ., Corvallis, Oregon. $452 \mathrm{pp}$.

Platts, W.S.. W.F. Megahan and G.W. Marshall. 1983. Methods for Evaluating Stream , Riparian and Biotic Conditions. U.S.D.A. Gen. Tech. Rept. INT-138, 70 pp.

Powell, G.R. ed. 1982. Nashwaak Experimental Watershed Project: Annual Report 198081. Nashwaak Experimental Watershed Project Technical Committee of the New Brunswick Forest Research Advisory Committee. 

Resource Handbook: Operational Guidelines for Industry. 1984. Prepared for Forest Land Use Branch, Forest Service, Alta. Ener. Nat. Res.

Ritchie, J.C. 1972. Sediment, Fish and Fish Habitat. J. Soil and Wat. Conserv. 27: 124.

Ringler, N.H. and J.D. Hall. 1975. Effects of Logging on Water Temperature and Dissolved Oxygen in Spawning Beds. Oregon State University. Amer. Fisheries Society Trans. 104 (1).

Rosenberg, D.M. and N.B. Snow. 1975a. Ecological Studies of Aquatic Organisms in the MacKenzie and Porcupine River Drainages in Relation to Sedimentation. Fish. Mar. Serv. Tech. Rep. No. 547. 49 pp.

Rosenberg, D.M. and A.P. Wiens. 1975b. Experimental Sediment Addition Studies on the Harris River, N.W.T.,Canada: The Effect on Macroinvertebrate Drift. Verein. Internatl. Verein. Limnol. 19: 1568-1574.

Rothwell, R.L. 1977a. Suspended Sediment and Soil Disturbance in a Small Mountain Watershed after Road Construction and Logging. In: Proc. Alberta Watershed Research Program Symposium Environment Canada, Canadian Forest Service. Rep. NOR-X-176.

Rothwell, R.L. 1977b. Watershed Management Guidelines for Logging and Road Construction in Alberta. Environment Canada, Canadian Forest Service. Rep. No. NOR-X-208.

Rothwell, R.L. 1979. Erosion Control at Road-Stream Crossings Hinton, Alberta, 1974-1975. Alberta Environmental Research Secretariat. Edmonton.

Schultz, C.D. and Company Ltd. 1973. The Environmental Effects of Timber Harvesting Operations in the Edson and Grande Prairie Forests of Alberta. Vol. 2. Project Report. Prepared for Minister of Lands and Forests, Gov. of Alta. Edmonton, Alta.

Scrivener, J.C. 1982. Logging Impacts on the Concentration Patterns of Dissolved Ions in Carnation Creek, British Columbia. In: Proceedings of the Carnation Creek Workshop: A 10 year Review. Hartman, G.F. (editor) Nanaimo, B.C.

Singh, T. and Y. Kalra. 1977. Impact of Pulpwood Clearcutting on Stream Water Quality in West-Central Alberta. pp. 272-284. In: Proc. Alberta Watershed Research Program Symposium. Environment Canada, Canadian Forest Service. Rep. NOR-X-176.

Sneddon, D.T. 1990. Hydrochemistry of the Tri-Creeks Experimental Watershed. Alta. Ener., Coal Res. and Sci. Engin. Branch. In-house document. 

Sterling, G.L. 1978. Population Dyanamics, Age, and Growth of Rainbow Trout (Salmo gairneri) and Dolly Varden (Salvelinus malma) in the Tri-Creek Watershed, 1971 to 1977. The Tri-Creeks Watershed Study Rep. No. 2. Alta. Ener. and Nat. Res., Alta. For. Serv. and Alta. Recreation, Parks and Wildlife, Fish and Wildlife Div., Edmonton.

Sterling, G.L.. 1980. Migratory Behaviour of the Major Salmonid Fishes, Rainbow Trout, Dolly Varden Char and Mountain Whitefish in the Tri-Creek Watershed, 1969 to 1978. The Tri-Creeks Watershed Study Rep. No. 6. Alta. Ener. and Nat. Res., Fish and Wildlife Div., Edmonton.

Sterling, G.L. 1987. An Evaluation of Spawning Habitat and Fry Escapement of Rainbow Trout (Salmo gairdneri Richardson) Before Logging in the Tri-Creek Watershed of WestCentral Alberta. The Tri-Creeks Watershed Study Rep. No. 8. Alta. Ener. and Nat. Res., Fish and Wildlife Div., Edmonton.

Sterling, G.L. 1990. Population Dynamics, Age and Growth of Rainbow Trout (Oncorhynchus mykiss) in the Tri-Creek Exerimental Watershed of West-Central Alberta; A Post-Logging Evaluation. Prepared for Alta. For. Lands and Wildl., Alta. Fish and Wildl. In-house document.

Swanson, R.H. 1980. Surface Wind Structure in Forest Clearing During a Chinook. pp. 26-30. In: Proc. West Snow Conf. 48th Annu. Meet., 15-17 April, 1980. Laramie, Wyoming.

Swanson, R.H. and G.R. Hillman. 1977. Predicted Increased Water Yield After ClearCutting Verified in West-Central Alberta. Can. For. Serv., Nor. For. Res. Cent. Edmonton, Alberta. Inf. Rep. NOR-X-198.

Tabler, R.D. and R.A. Schmidt. 1973. Weather Conditions that Determine Snow Transport Distances at a Site in Wyoming. pp. 118-127. In: Proc. The Role of Snow and Ice in Hydrology. World Meteorol. Organ., Geneva, Switzerland.

Troendle, C. and C. Leaf. 1980. Hydrology, Chapter III. In: An Approach to Water Resources Evaluation of Non- Point Silvicultural Sources. Environmental Research Laboratory, Athens, Georgia. EPA 60018-80-012. 173 pp.

U.S. Federal Water Pollution Control Federation. 1968. Water Quality Criteria. Report of the National Technical Advisory Committee to the Secretary of the Interior, Washington. $234 \mathrm{pp}$.

Wallace. R.R. and K. Strong-Duffin. 1985. A review of Water Quality for the Protection of Fish and Other Aquatic Life. Dominion Ecological Consulting Ltd., Calgary, Alta. Prepared for Alta. Fish and Wildlife Div., Alta. Forestry, Lands and Wildlife. 164 pp. 

Wasiliew, W. 1986. Sediment Dynamics in an Alberta Foothill Streams Following Clearcut Logging. Alta. Forestry and Wildlife, Forest Research Branch. In-house document.

Wischmeier, W.H. and D.D. Smith. 1965. Predicting Rainfall-Erosion Losses from Cropland East of the Rocky Mountains. U.S. Dept. of Agric., Agric. Res. Serv. Agricultural Handbook No. 282, 47 pp.

Zelt, K.A. 1970. The Mayfly (Ephemeroptera) and Stonefly (Plecoptera) Fauna of a Foothills Stream in Alberta with Special Reference to Sampling Techniques. M.Sc. Thesis, Univ. of Alberta. 




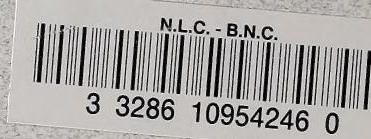

